\title{
47. PALEOCENE AND EOCENE CALCAREOUS NANNOFOSSILS FROM DEEP SEA DRILLING PROJECT LEGS 25 AND 40, SOUTH AND EAST OF AFRICA ${ }^{1}$
}

\author{
Duncan T. MacKenzie, III, ${ }^{2}$ and Sherwood W. Wise, Jr., Department of Geology, Florida State University, \\ Tallahassee, Florida
}

\begin{abstract}
Paleocene and Eocene nannofossil flora from Deep Sea Drilling Project Legs 25 and 40 were analyzed in order to provide a basis of comparison with DSDP Legs 36 and 71 and with other South Atlantic assemblages. A mid-latitude biostratigraphic zonation, using previously described zonal markers, was adopted for the southwest Indian Ocean. Various diagenetic effects were noted in the sedimentary sequences. Some of these mask to some extent paleoecologic signals, particularly those generated by the Discoaster/Chiasmolithus ratio.
\end{abstract}

\section{INTRODUCTION}

A significant result of deep sea drilling in the vicinity of the Falkland Plateau during DSDP Legs 36 (Barker, Dalziel, et al., 1977) and 71 (this volume) was the recovery of extensive high-latitude Paleogene carbonate sediments. However, there exist below $30^{\circ}$ South in the South Atlantic few other drill sections to which the Leg 36 and 71 sequences can be compared. One may be obliged, therefore, to turn to drill sequences in the southwestern Indian Ocean to fill in gaps for regional Paleogene biogeographic, biostratigraphic, and paleoceanographic studies in this part of the Southern Hemisphere. Unfortunately, stringent deadlines precluded the publication of detailed biostratigraphic data in the DSDP Initial Reports for the several southeastern Indian Ocean sites drilled during DSDP Leg 25 (Simpson, Schlich, et al., 1974; see Fig. 1), and species distributions and abundances of calcareous microfossils were largely unreported. The present study, therefore, was undertaken to examine in more detail than originally published the calcareous nannofossil content of Paleocene to Eocene cores recovered during DSDP Leg 25.

In addition to the Leg 25 material, Paleocene and Eocene samples from DSDP Leg 40, Holes 360 and 361, were examined (Bolli, Ryan, et al., 1978). The samples provide good control because their latitude is similar and they are relatively close to Leg 25 sites (Leg 40 was off the Cape of Good Hope, South Africa); they therefore provide a check on the accuracy of the zonation adopted for the Leg 25 material. The Leg 40 samples cover the upper Paleocene through Eocene, whereas the Leg 25 samples also include the lower Paleocene.

The fourth of six cruises designed to investigate the marine geology of the Indian Ocean, Leg 25 began in June, 1972, the 100th anniversary of the voyage of H.M.S. Challenger. Among the objectives for this leg

\footnotetext{
${ }^{1}$ Ludwig, W. J., and Krasheninnikov, V. A., Init. Repts. DSDP, 71: Washington (U.S. Govt, Printing Office).

2 Present address: DeGolyer and MacNaughton, One Energy Square, Dallas, Texas 75206.
}

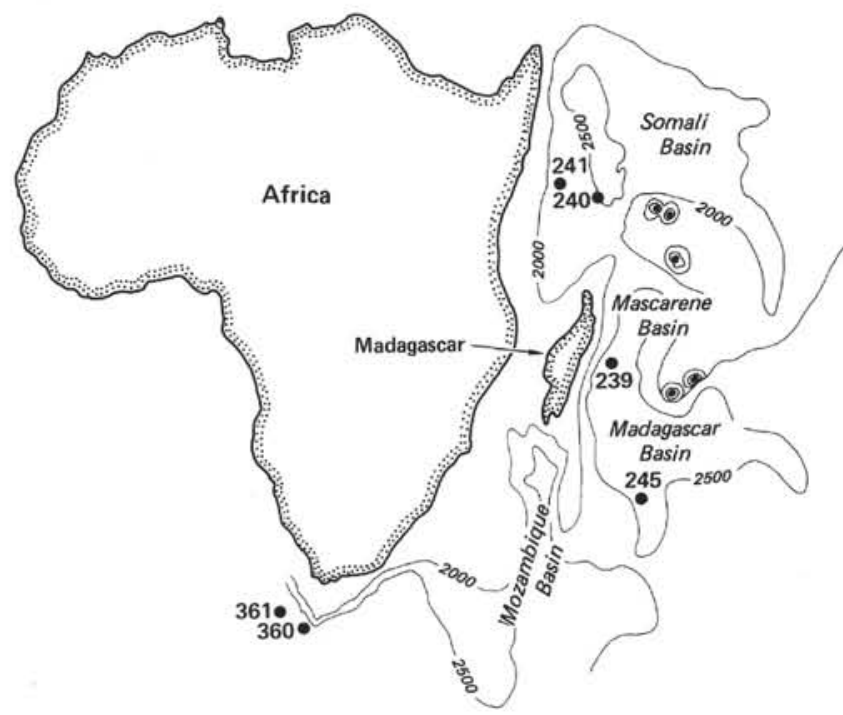

Figure 1. Location map for Leg 25 and Leg 40 sites.

was the establishment of a mid-latitude biostratigraphic zonation above the carbonate compensation depth (CCD).

As the shipboard coccolith stratigrapher for Leg 25, Müller (1974) offered age dates for cores and some discussion of dissolution and/or paleoecology of the nannofloras, but her report did not contain range charts for occurrences of individual taxa. Instead, Martini's (1970, 1971) zonation was used to assign zones to each $150 \mathrm{~cm}$ core section. Muller's brief discussion of dissolution sequences reflected observations published prior to the Leg 25 Initial Reports (e.g., Bukry, 1971b, 1973b; Roth, 1973; Wise, 1973.). Müller noted that overgrowths are due mainly to the sediment type. Nannofossil ooze was described as having poorly preserved coccoliths whereas the preservation in marl ooze was good to excellent.

Bukry (1974) age dated the Leg 25 core sections using his low-latitude zonation (Bukry, 1973a). He presented a range chart for 11 lower Eocene samples from Site 245 but did not indicate species abundances. He also calcu- 
lated Discoaster/Chiasmolithus ratios for these samples and compared the results to other regions (see the following section, which explains his use of this paleoecologic tool).

Detailed range charts but no species abundances were plotted for the Leg 40 sites by Proto Decima et al. (1978). These results were not available by the conclusion of the present study, so the data on these sites presented here were arrived at independently. Bukry (1978) also age dated the Leg 40 core sections and calculated Discoaster/ Chiasmolithus ratios for four upper Eocene samples (Bukry, 1978; Figs. 2 and 3, this chapter).

\section{BACKGROUND STUDIES}

\section{Paleoecology}

Modern calcareous nannoplankton are most abundant in low and middle latitudes with no living representatives in polar water masses (McInytre et al., 1967). Although the greatest species diversity is in low latitudes, the few species restricted to higher latitudes are frequent- ly more abundant in total number of cells/liter than in lower latitudes (Lisitzin, 1972).

Data compiled by McIntyre and his colleagues suggest that various species of coccolithophorids are limited by surface water temperatures. These observations led to the construction of general temperature-floral zones: subarctic-subantarctic, transitional, subtropi$\mathrm{cal}$, and tropical.

Paleotemperature inferences for Tertiary calcareous nannoplankton are based on more indirect evidence than those of Quaternary species. Bukry (1971b) proposed that coccolith assemblages with a limited diversity or small size and shape are typical of cooler water. Siesser (1975) believes this may also apply to assemblages of discoasters, which are associated with warmer surface water temperatures because of their abundance in lowlatitude sediments. Increased numbers of chiasmoliths in high-latitude sediments suggest an affinity for cool surface water temperatures. This led Bukry (1973b) to propose the Discoaster/Chiasmolithus ratio as a means of determining surface water temperature.

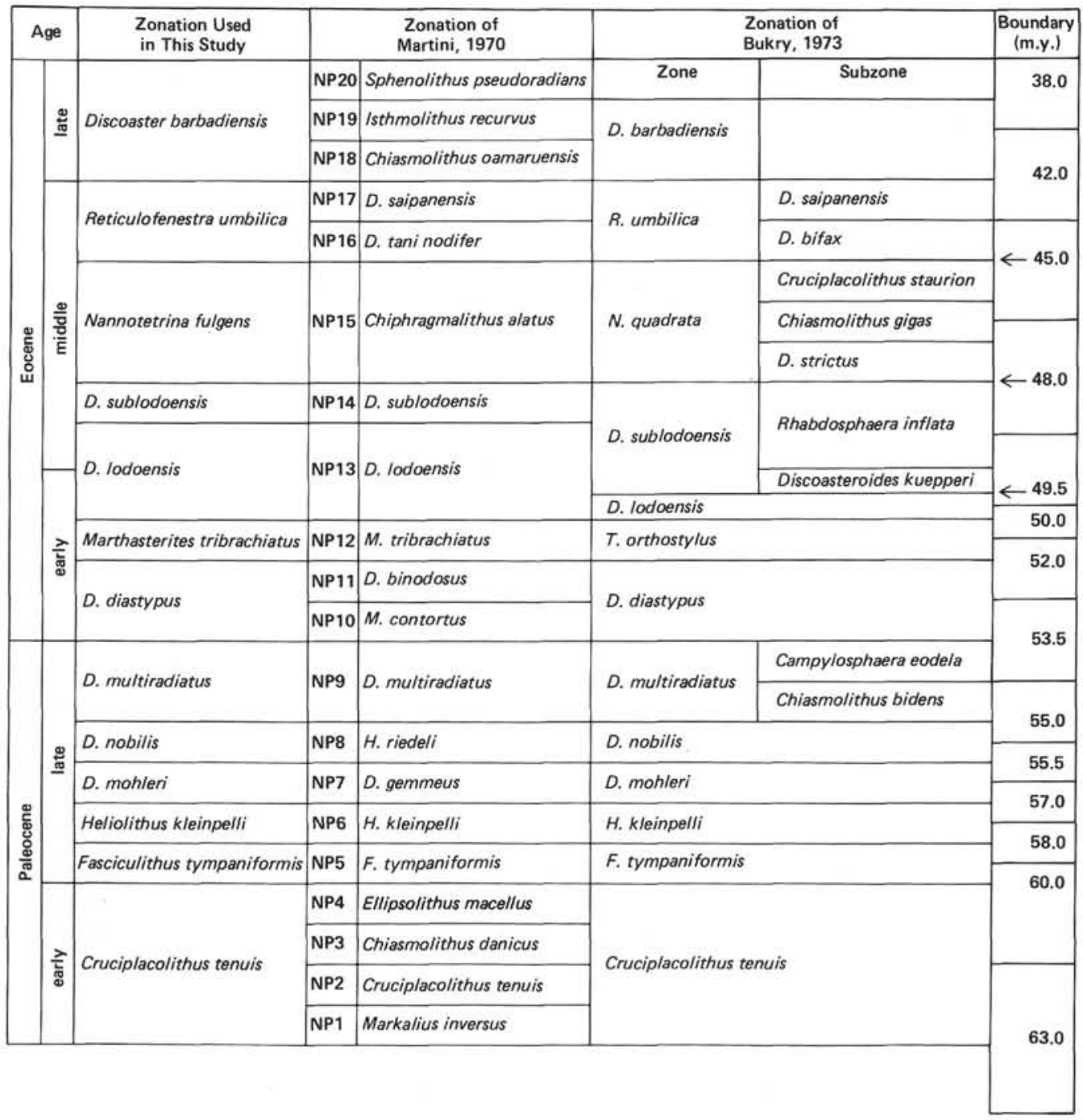

Figure 2. A comparison of the zonations used in this paper, by Bukry (1973a), and by Martini (1970), along with relative ages originally modified from Perch-Nielsen (1972) to Bukry's zonation (1973a). 


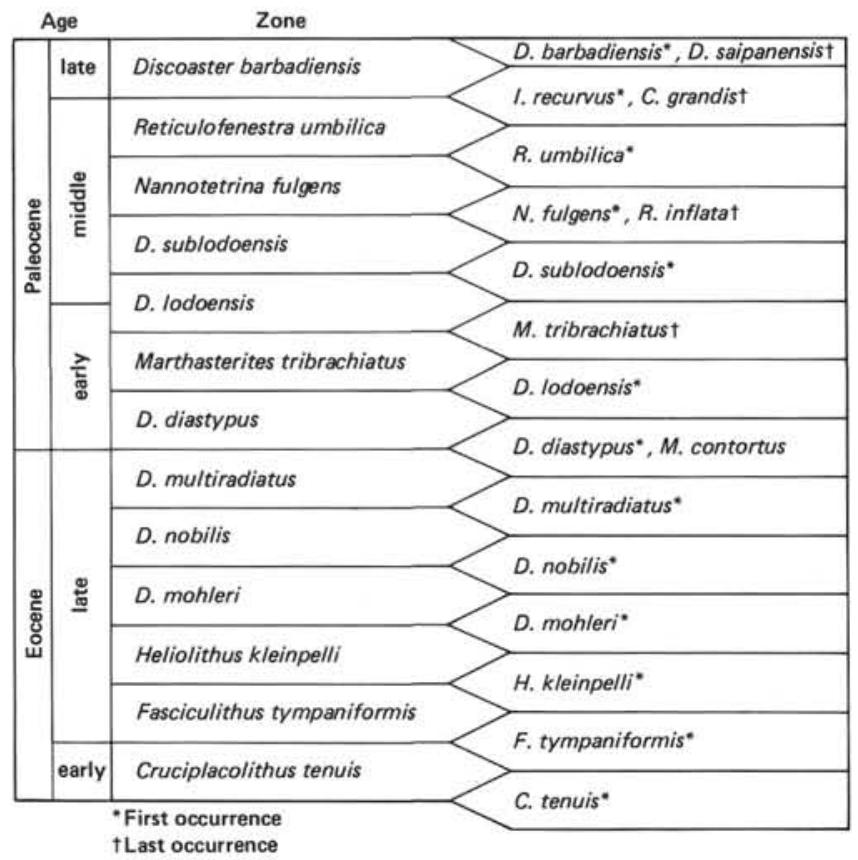

Figure 3. Zonation adopted for this study, modified from Bukry (1973a) and Martini (1970).

The following list of "cool-water" and "warm-water" species was compiled by Siesser (1975) from data presented by Martini (1970), Bukry (1971a, 1973b), Edwards (1973), Wise (1973), and Thierstein (1974):

\begin{tabular}{ll}
\hline \multicolumn{1}{c}{ Cool-water forms } & Warm-water forms (cont.) \\
Chiasmolithus oamaruensis & C. rugosus \\
Coccolithus pelagicus & Discoaster barbadiensis \\
Cyclicargolithus floridanus & D. brouweri \\
Calcidiscus macintyrei & D. neohamatus \\
Discoaster deflandrei & D. pentaradiatus \\
D. exilis & D. quinqueramus \\
D. intercalaris & D. saipanensis \\
D. variabilis & D. surculus \\
Isthmolithus recurvus & Gephyrocapsa protohuxleyi \\
Lanternithus minutus & Helicopontosphaera spp. \\
Neococcolithus dubius & Reticulofenestra umbilica \\
Reticulofenestra pseudoumbilica & Scyphosphaera spp. \\
Warm-water forms & Sphenolithus spp. \\
Braarudosphaera spp. & Transversopontis spp. \\
Ceratolithus cristatus & Triquetrorhabdulus rugosus
\end{tabular}

Biogeographic distribution patterns of early Cenozoic calcareous nannoplankton from the Atlantic Ocean were computer-plotted to determine what assemblages (if any) might be used to indicate latitudinal temperature fluctuations with time (Haq and Lohmann, 1976). The Paleogene was subsequently divided into 23 latitudinaltemperature assemblages.

\section{Dissolution/Preservation}

The concept of carbonate dissolution with depth was first proposed by Murray and Renard (1891) of the Challenger Expedition. Upon further investigation, Bramlette (1961) suggested the presence of a depth zone, narrow and well defined, separating carbonate-rich from carbonate-poor sediments. This observation gave rise to the concept of the "carbonate compensation depth" (CCD) and stimulated research on coccolith deposition with respect to the CCD.

Berger (1975) recognizes several first-order features of the CCD: (1) a mean subsea depth of $4.5 \mathrm{~km}$ as measured halfway between ridge crests and the deepest parts of the seafloor, exclusive of trenches; (2) a shallower $\mathrm{CCD}$ in the Pacific because of old, $\mathrm{CO}_{2}$-rich bottom water; (3) a depressed CCD under the equatorial Pacific because of upwelling and the resulting increase in productivity; and (4) a rising CCD near continental margins (see also Ramsay, 1977).

The Peterson buoy experiment (Peterson, 1966) tested partial dissolution of calcareous material above the CCD. This established the facts that dissolution occurs over a wide range of depths above the CCD and that a boundary (lysocline) marked by a sharp increase in the dissolution rate exists at a depth shallower than the CCD.

Calcareous nannoplankton generally live in the photic zone. When the algal cell dies, the cytoplasmic membrane decomposes and the coccolithophorids disintegrate, freeing the individual coccoliths. Although these platelets may suffer some dissolution while descending through the water column, more extensive deterioration-etching, fragmentation, and differential removal of weakly resistant species (Roth, Wise, et al., 1975) occurs in the bottom sediment near the sediment-water interface (Wise, 1973). Breakdown of the skeletal material helps determine the "diagenetic potential" (Schlanger and Douglas, 1974) of the material for further deterioration following burial.

Preservation of the coccoliths is controlled to varying degrees by a number of factors. Müller (1974) suggests preservation is primarily controlled by the sediment type: In deep sea sediments from the southwest Indian Ocean, Müller describes heavy overgrowths occurring in nanno ooze, with less overgrowth in marl ooze. Nannofossils were preserved only within micronodules of brown clays and were rare or missing in epicontinental sediments.

Roth, Mullin, et al. (1975) consider that the size of individual crystallites is a primary factor determining coccolith preservation: Solution resistant taxa have larger crystallites (e.g., Nannotetrina, Coccolithus, Marthasterites) whereas species with fine-grained structures (e.g., Corollithion, Haysites, Chiasmolithus) are more susceptible to solution.

Honjo (1976) asserted that the mode of deposition plays a primary role in the response of dissolution and overgrowth. He suggests that a discrete coccolith, sinking at a rate of 0.15 meters/day, would dissolve upon passing beyond the calcite saturation depth (CSD). The presence of coccolith ooze in the North Pacific Ocean, at depths greater than the CSD, requires another mode of deposition. Predator fecal pellets have been recognized as an important method of rapidly transporting coccoliths to the ocean floor $(160 \mathrm{~m} /$ day $)$, thereby preventing dissolution during descent (Roth, Mullin, et al., 1975; Honjo, 1976).

In a study of the Atlantic Ocean's compensation zone, Schneidermann $(1973,1977)$ found a close relationship 
between the elemental structure of coccoliths and the depth of deposition with respect to solution. He recognized three depth zones. They are, from the lowest part of the compensation zone to the highest:

1) the mesolytic zone where sediments are characterized by intense solution, leaving a few solution-resistant placoliths. The zone extends upward for $500 \mathrm{me}-$ ters from the CCD in the equatorial Atlantic.

2) The oligolytic zone is defined by a rapid increase in the rate of dissolution of planktonic foraminifers and calcareous nannoplankton. Removal of soluble coccoliths and etching of solution-resistant species are secondary features. The absolute depth range is between 5500 meters and $4400-4500$ meters.

3) The eolytic zone is the region of initial dissolution, where sediments are characterized by well-preserved planktonic foraminifers and a diversified nannoplankton assemblage depleted in weakly resistant groups and showing signs of initial dissolution. The upper boundary is poorly defined, but the zone is at least 1500 meters thick and is separated from the CCD by 1500 meters.

Schneidermann found the distal shields of placoliths to be more resistant to solution than the proximal shield, because the calcareous elements of the distal shield are aligned perpendicular to the optic $\mathrm{C}$-axis within solution-resistant groups (e.g., Coccolithus, Calcidiscus, Discoaster). In contrast, the optic axes of proximal shield elements and weakly resistant coccoliths are inclined to the surface. Because dissolution occurs more readily along the $\mathrm{C}$-axis, parallel orientation may effectively minimize solution. Schneidermann concluded that the dissolution sequence of coccoliths is dependent upon crystallographic orientation, the degree of imbrication, and protection by organic envelopes.

The effects of dissolution do not end at the sediment/ water interface but continue within the sediment after burial. Little calcite is actually liberated from the sediment pile through in situ dissolution (Roth, Wise, et al., 1975). Rather, it tends to reprecipitate as overgrowths on stable or accommodating surfaces. Large nannofossils which exhibit optical and crystallographic continuity can act as "seed crystals" and certain species or different anatomical parts of coccoliths may be more susceptible to overgrowths than others. Wise and Kelts (1972, pl. 3, figs. 1-2) found secondary overgrowths on the undersides of the proximal shield of the genus Coccolithus but none on the top and central areas of the shield.

Taxonomic problems arising from postdepositional overgrowths have confused the status of a number of species of Discoaster (e.g., D. extensus, D. woodringii, and $D$. aster). When these and other forms could not be recognized outside local areas, it was concluded that they were not true biological forms, but overgrown taxa. For discussions, see Bukry, 1973b; Roth, 1973; Roth and Thierstein, 1972; Roth, Wise, et al., 1975; Wise, 1972, 1973, 1976.)

The inherent problems of dissolution and overgrowth are numerous and complex. This paper is restricted to a discussion of a dissolution sequence at Site 245, along with probable causes for alterations in preservation, ex- amples of taxonomic problems, and complications with biostratigraphy.

\section{METHODS AND PROCEDURES}

Whereas most of the DSDP core sections utilized in this study were sampled twice, barren cores were generally sampled once. Biostratigraphic boundaries were pinpointed by close sampling near boundaries previously described in the Initial Reports for Leg 25 and the Initial Core Descriptions for Leg 40.

Smear slides and 20-30 min. settling preparations for calcareous nannofossils were primarily for identification, biostratigraphic zonation, dissolution studies, and abundance counting of certain genera (i.e., Chiasmolithus, Discoaster) for paleotemperature investigations. Settling solutions were prepared by placing samples in a beaker of distilled water, adding a small amount of the detergent Triton X-100 to break down the clays and separate the calcareous nannofossils, mixing, and allowing to settle for $15 \mathrm{~s}$. Foraminifers and larger particles in the bottom sediment are discarded, and the remaining liquid suspension is allowed to settle for another 20-30 min. Most of the clay particles remain suspended while the coccoliths settle to the bottom of the beaker. Slides or SEM stubs are made from the resulting calcareous nannofossil concentration. For SEM samples 2 or 3 drops of the 20-30 min. settling solution are placed on a glass cover slip glued to an SEM stub, air dried, and coated in a vacuum with carbon and goldpaladium.

Nannofossil species abundances were tabulated in the light microscope using the system proposed by Hay (1970), whereby abundance is assigned a number which corresponds to the log (base ten) of the number of specimens of a particular species that are probably present in any one field of view at $1000 \times$, as follows:

$\mathrm{V}=$ very abundant, +1 (more than 10 specimens/field of view)

$\mathrm{A}=$ abundant, 0 (1 to 10 specimens/field of view)

$\mathrm{C}=$ common, -1 ( 1 specimen $/ 2-10$ fields of view)

$\mathrm{F}=$ few,$-2(1$ specimen $/ 11-100$ fields of view $)$

$\mathrm{R}=$ rare, -3 (1 specimen/101-1000 fields of view)

The percentage of discoasters in a given sample has been used as an indicator of the intensity of dissolution the sample has undergone (Ramsay, 1972; Ramsay et al., 1973). The ratio of discoasters to placoliths was calculated in every sample, starting in the Discoaster multiradiatus Zone and continuing through the Eocene. Counts of 200-300 specimens (Constans, 1975) were made at intervals of preservation change.

A similar study was conducted using the ratio of Discoaster (warm-water forms) to Chiasmolithus (cold-water forms) as an indicator of changing climate and relative temperature (Bukry, 1973b). Counts of 200-300 were again used, except in samples where dissolution limited the number of individual coccoliths to one or less per field of view. Poorly preserved samples were considered unreliable for this technique and were not used.

Species considered in this study are listed in Appendices A and B. Most bibliographic references for these taxa are presented by Loeblich and Tappan $(1966,1968,1969,1970 \mathrm{a}, 1970 \mathrm{~b}, 1971$, and 1973) and by Heck (1979a, 1979b, 1980); any not included therein are given in the references.

\section{ZONES AND OCCURRENCES}

The zonation utilized in this paper (Fig. 3) is based on the zonations of Bukry (1973a) and Martini (1970). Only zones and associated assemblages will be presented. Subzones are not included because of their restricted utility in biostratigraphy and also because a paleoenvironmental analysis of the southwest Indian Ocean during the Paleocene and Eocene will be made separately.

\section{Cruciplacolithus tenuis Zone}

Definition. Base defined by the first occurrence of Cruciplacolithus tenuis and top by the first occurrence of Fasciculithus tympaniformis.

Author. Mohler and Hay, 1967. 
Associated species. Cruciplacolithus tenuis, Chiasmolithus danicus, Coccolithus cavus, Markalius inversus, Thoracosphaera spp., Zygodiscus sigmoides.

Comment. Whereas Martini (1970) recognizes four zones in the lower Paleocene (NP1-NP4), poor preservation limited this zonation to one. At Site 245, the Cruciplacolithus tenuis Zone is probably conformable with underlying basalt, cored and dated as 68-69 Ma from magnetic anomalies (Schlich, 1974).

Occurrence. Samples $245-16-1,125-127 \mathrm{~cm}$ to 245 13-4, 110-112 cm; Sample 361-10-1, 122-123 cm.

\section{Fasciculithus tympaniformis Zone}

Definition. Base defined by the first occurrence of Fasciculithus tympaniformis and top by the first occurrence of Heliolithus kleinpelli.

Authors. Mohler and Hay, 1967.

Associated species. Fasciculithus involutus, F. tympaniformis, Cruciplacolithus tenuis, Toweius eminens, Chiasmolithus bidens, C. danicus.

Comment. High resistance to solution of the assemblage species makes this zone easily recognizable, even with poor preservation.

Occurrence. Samples 239-17-2, 124-126 cm to 239$15-1,148-150 \mathrm{~cm} ; 245-13-4,33-34 \mathrm{~cm}$ to $245-11-5,133-$ $135 \mathrm{~cm}$.

\section{Heliolithus kleinpelli Zone}

Definition. Base defined by the first occurrence of Heliolithus kleinpelli and top by the first occurrence of Discoaster mohleri.

Authors. Mohler and Hay, 1967.

Associated species. Markalius inversus, Fasciculithus tympaniformis, Toweius craticulus, Cruciplacolithus tenuis, Chiasmolithus danicus.

Comment. Unusually large size $(\sim 20 \mu \mathrm{m})$ and the high resistivity to solution of Heliolithus kleinpelli make this zone easily recognizable.

Occurrence. Samples 245-11-5, 56-58 cm to 245-10-3, $102-104 \mathrm{~cm}$.

\section{Discoaster mohleri Zone}

Definition. Base defined by the first occurrence of Discoaster mohleri and top by the first occurrence of $D$. nobilis.

Author. Bukry, 1971a.

Associated species. Fasciculithus involutus, Fasciculithus tympaniformis, Toweius eminens, Cruciplacolithus tenuis.

Comment. This zone is equivalent to Martini's (1970) NP7-Discoaster gemmeus Zone and marks the first occurrence of the long-ranging genus Discoaster.

Occurrence. Sample 245-10-3, 55-57 cm to 245-10-1, 70-72 cm.

\section{Discoaster nobilis Zone}

Definition. Base defined by the first occurrence of Discoaster nobilis and top by the first occurrence of $D$. multiradiatus.

Author. Perch-Nielsen, 1972.
Associated species. Fasciculithus tympaniformis, Heliolithus cantabriae, Toweius eminens, Cruciplacolithus staurion.

Comment. This zone is equivalent to Bramlette and Sullivan's (1961) Heliolithus riedeli Zone.

Occurrence. Sample 361-9-3, 91-93 cm.

\section{Discoaster multiradiatus Zone}

Definition. Base defined by the first occurrence of Discoaster multiradiatus and top by the dual first occurrance of $D$. diastypus and Marthasterites contortus.

Authors. Bramlette and Sullivan, 1961.

Associated species. Discoaster nobilis, Fasciculithus tympaniformis, $F$. magnus, Toweius eminens.

Comment. The top of this zone marks the upper boundary of the upper Paleocene.

Occurrence. Samples 240A-3,CC, 245-9-3, 120-122 $\mathrm{cm}$ to $245-9-2,72-74 \mathrm{~cm} ; 361-9-2,51-53 \mathrm{~cm}$.

\section{Discoaster diastypus Zone}

Definition. Base defined by the first occurrence of Discoaster diastypus and top by the first occurrence of D. lodoensis.

Author. Hay, 1964.

Associated species. Chiasmolithus grandis, Coccolithus pelagicus, Discoaster multiradiatus, Marthasterites tribrachiatus, Cruciplacolithus staurion.

Comment. This zone corresponds to Martini's (1970) NP10-Marthasterites contortus Zone and NP11-Discoaster binodosus Zone. The bottom of this zone marks the lower boundary of the lower Eocene.

Occurrence. Samples 245-9-2, 27-29 $\mathrm{cm}$ to 245-8-1, $55-57 \mathrm{~cm} ; 361-8-6,101-103 \mathrm{~cm}$ to $361-8-1,131-133 \mathrm{~cm}$.

\section{Marthasterites tribrachiatus Zone}

Definition. Base defined by the first occurrence of Discoaster lodoensis and top by the last occurrence of Marthasterites tribrachiatus.

Authors. Brönnimann and Stradner, 1960.

Associated species. Coccolithus formosus, C. pelagicus, Reticulofenestra samodurovi, Neococcolithus dubius, Discoaster barbadiensis, Chiasmolithus bidens.

Comment. This zone corresponds to Bukry's (1973a) Tribrachiatus orthostylus Zone.

Occurrence. Sample 245-7-2, 140-142 cm to 245-6-2, $138-140 \mathrm{~cm}$.

\section{Discoaster lodoensis Zone}

Definition. Base defined by the last occurrence of Marthasterites tribrachiatus and top by the first occurrence of Discoaster sublodoensis.

Authors. Brönnimann and Stradner, 1960.

Associated species. Coccolithus formosus, Discoaster lodoensis, Reticulofenestra samodurovi, Neococcolithus dubius, Chiasmolithus bidens, Coccolithus eopelagicus.

Comment. This zone corresponds to Bukry's (1973a) Discoaster lodoensis Zone. Bukry uses the first occurrence of Coccolithus crassus to define the base. 
Occurrence. Sample 245-6-2, 64-66 cm to 245-4-3, $135-137 \mathrm{~cm} ; 245 \mathrm{~A}-7-6,133-135 \mathrm{~cm}$ to $245 \mathrm{~A}-7-4,105-$ $107 \mathrm{~cm}$.

\section{Discoaster sublodoensis Zone}

Definition. Base defined by the first occurrence of Discoaster sublodoensis and top by the first occurrence of Nannotetrina fulgens.

Author. Hay, 1964.

Associated species. Coccolithus formosus, Reticulofenestra samodurovi, Neococcolithus dubius, Discoaster barbadiensis, Chiasmolithus bidens.

Comment. This zone corresponds to Martini's (1970) NP14-Discoaster sublodoensis Zone. Nannotetrina fulgens (this study), N. quadrata (Bukry, 1973a), and Chiphragmalithus alatus (Martini, 1970) are different names for the same species, a marker fossil that begins in the middle Eocene.

Occurrence. Sample 245-4-2, 143-145 cm to 245-4-1, $30-32 \mathrm{~cm} ; 245 \mathrm{~A}-7-4,42-44 \mathrm{~cm}$ to $245 \mathrm{~A}-7-1,135-137$ $\mathrm{cm} ; 361-7-1,111-113 \mathrm{~cm}$ to $361-4-1,137-139 \mathrm{~cm}$.

\section{Nannotetrina fulgens Zone}

Definition. Base defined by the first occurrence of Nannotetrina fulgens and top by the first occurrence of Reticulofenestra umbilica.

Author. Bukry, 1971a.

Associated species. Reticulofenestra coenura, Reticulofenestra samodurovi, Chiasmolithus grandis, Coccolithus formosus.

Comment. This zone corresponds to Martini's (1970) NP15-Chiphragmalithus alatus Zone and is also equivalent to Bukry's (1973a) Nannotetrina quadrata Zone.

Occurrence. Sample 245-3-6, 111-113 cm to 245-3-4, 62-64 cm; 245A-6-3, 144-146 cm to 245A-6-1, 104-106 $\mathrm{cm} ; 360-50-1,122-124 \mathrm{~cm}$ to $360-49-1,130-132 \mathrm{~cm}$.

\section{Reticulofenestra umbilica Zone}

Definition. Base defined by the first occurrence of Reticulofenestra umbilica and top by the first occurrence of Isthmolithus recurvus and the last occurrence of Chiasmolithus grandis.

Author. Bukry, 1971c.

Associated species. Discoaster tani nodifer, D. saipanensis, Coccolithus formosus, Chiasmolithus oamaruensis.

Comment. The lower half of this zone corresponds to Martini's (1970) NP16-Discoaster tani nodifer Zone.

Occurrence. Samples 245-3-3, 110-112 cm to 245-3-1, $80-82 \mathrm{~cm} ; 245 \mathrm{~A}-5-4,120-122 \mathrm{~cm}$ to $245 \mathrm{~A}-5-1,107-109$ $\mathrm{cm} ; 360-48-5,70-71 \mathrm{~cm}$ to $360-39-3,56-58 \mathrm{~cm}$.

\section{Discoaster barbadiensis Zone}

Definition. The base of this zone is defined by the first occurrence of Isthmolithus recurvus and the last occurrence of Chiasmolithus grandis and top by the dual last occurrence of Discoaster saipanensis and D. barbadiensis.

Authors. Brönnimann and Stradner, 1960.

Associated species. Isthmolithus recurvus, Chiasmolithus oamaruensis, Discoaster barbadiensis, D. saipanensis.
Comment. This zone corresponds to Martini's (1970) NP17-Discoaster saipanensis Zone, NP18-Chiasmolithus oamaruensis Zone, NP19-Isthmolithus recurvus Zone, and NP20-Sphenolithus pseudoradians Zone. The top of this zone marks the Eocene/Oligocene boundary.

Occurrence. Sample $245 \mathrm{~A}-4-5,115-117 \mathrm{~cm}$ to $245 \mathrm{~A}-$ $2-2,103-105 \mathrm{~cm} ; 360-39-1,126-128 \mathrm{~cm}$ to $360-36-2$, $44-46 \mathrm{~cm}$.

\section{SITE SUMMARIES: DSDP LEG 25}

Background information and detailed descriptions of cores, from the following drill sites are given in the appropriate site chapters of the DSDP Leg 25 Initial Reports (Simpson, Schlich, et al., 1974).

Site 245 (Tables 1-2, Fig. 4) $\left(1^{\circ}{ }^{\circ} \mathrm{rog}^{\prime} \mathrm{S}, \mathbf{4 1}^{\circ} 49.23^{\prime} \mathrm{E}\right.$; sonic depth $2275 \mathrm{~m}$ )

Hole 245, located southeast of the Malagasy Republic, in the Madagascar Basin, penetrated nearly 400 meters of sediment ranging from lower Paleocene to lower Oligocene. Basalt recovered in cores was dated as Late Cretaceous or early Paleocene (Schlich, 1974).

The lower Paleocene at Hole 245 is characterized by clayey nanno chalk grading to clay-rich nanno chalk; the coccoliths are poorly preserved, etched, and fragmented. The rate of deposition for the lower Paleocene was approximately $11 \mathrm{~m} / \mathrm{m} . y$. Ericsonia subpertusa, Cruciplacolithus tenuis and thoracosphaerids typify the lower Paleocene nannoflora at this site.

The upper Paleocene lithologies consist of a clay-rich nanno chalk with silicified interbeds and beds of chert. Coccolith preservation is poor to moderate with etching and overgrowth present in most samples. Species diversity doubles in the upper Paleocene but the rate of sedimentation remains stable $(10+\mathrm{m} / \mathrm{m} . \mathrm{y}$.). A characteristic assemblage for this series includes $E$. subpertusa and Prinsius bisulcus. Although not actually sampled, the Discoaster nobilis Zone, if it exists at this site, lies within the sampled intervals $245-10-1,70-72 \mathrm{~cm}$ and $245-$ 9-3, 120-122 cm.

The clay-rich nannochalk of the upper Paleocene extends halfway into the lower Eocene and then grades into clay-bearing and clay-rich nanno ooze. Preservation is generally poor to moderate with one exception (good preservation in Sample 245-8-1, 138-140 cm). Depositional rates during the early Eocene were high, approximately $43 \mathrm{~m} / \mathrm{m}$.y. A typical assemblage includes Discoaster multiradiatus, $D$. diastypus, $D$. lodoensis, Coccolithus pelagicus, and $C$. formosus.

The Discoaster lodoensis Zone is approximately evenly divided between the lower and middle Eocene (Marti$\mathrm{ni}, 1970$ ). Assuming the time interval for this zone to be about $1 \mathrm{~m}$.y. (Bukry, 1973a), deposition during this substage was approximately $182 \mathrm{~m} / \mathrm{m} . \mathrm{y}$.

The middle Eocene is represented by clay-bearing and clay-rich nanno ooze overlain by nanno ooze and nanno-bearing clay. Preservation in this stage ranges between poor and good. The rate of deposition for the middle Eocene at this site is $11 \mathrm{~m} / \mathrm{m}$.y. The assemblages present consist primarily of Discoaster barbadiensis, $D$. 
Table 1A. Distribution of calcareous nannofossil species, Leg 25, Hole 245: Sample 245-3-1, 80-82 cm to Sample 245-6-2, 64-66 cm.

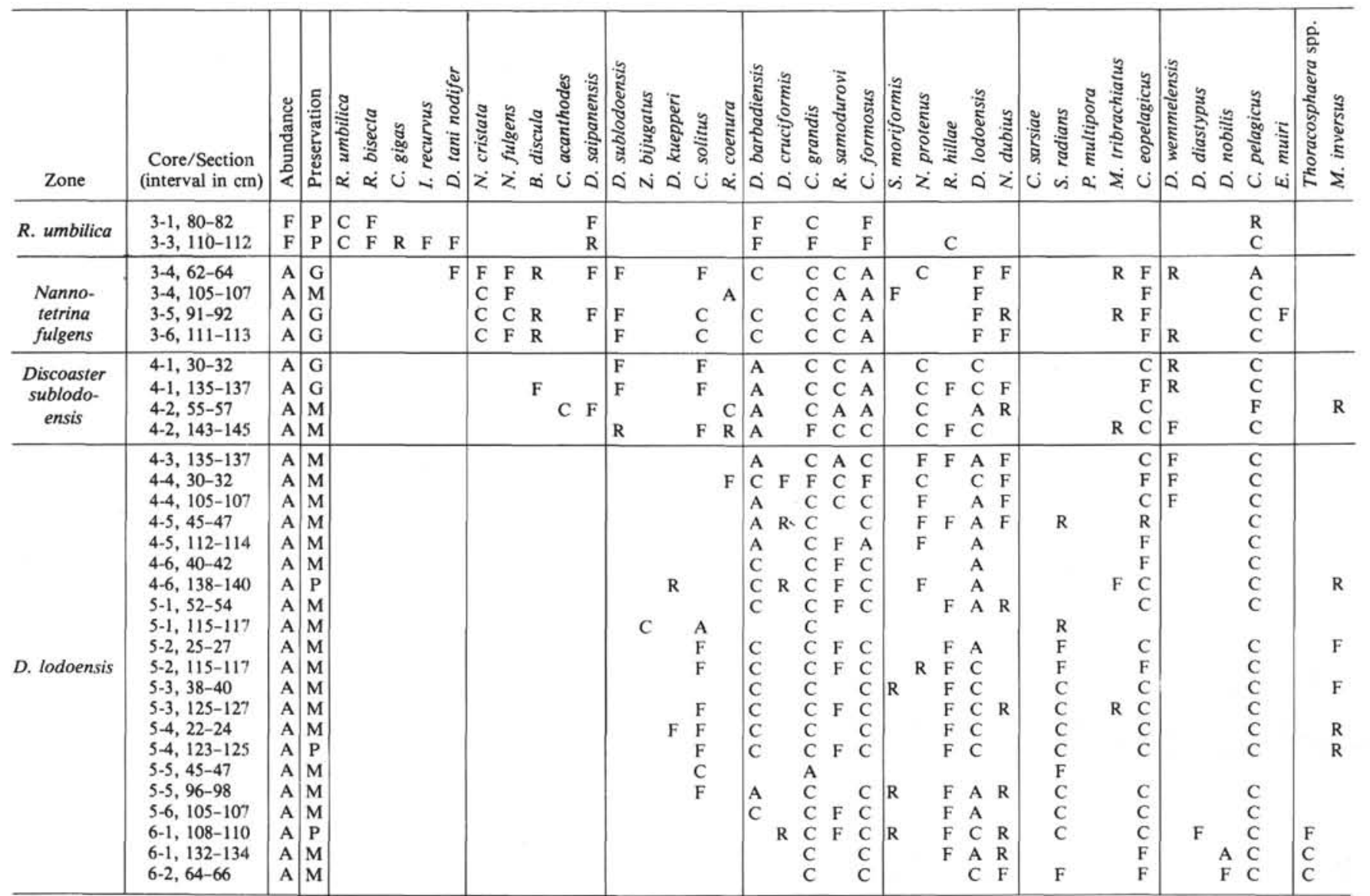

Note: For abundance, $\mathrm{R}=$ rare, $\mathrm{F}=$ few, $\mathrm{C}=$ common, $\mathrm{A}=$ abundant, $\mathrm{V}=$ very abundant (for quantitative values see text). For preservation, $\mathrm{P}=$ poor, $\mathrm{M}=$ moderate, $\mathrm{G}=$ good. For genus names, see Appendix $\mathrm{A}$.

lodoensis, Reticulofenestra samodurovi, R. umbilica, $R$. bisecta, Coccolithus formosus, and C. pelagicus.

Hole 245A (Table 2) was drilled at the same site to provide a better stratigraphic sequence of Eocene material. Lithologies cored are identical with those of Hole 245 . The oldest sediments recovered are probably early middle Eocene.

Middle Eocene samples from Hole 245A indicate that preservation of nannofossils in the upper middle Eocene is poor. The Discoaster-Reticulofenestra-Coccolithus assemblage described by Haq and Lohmann (1976) appears to be valid for this sequence. A sample barren of calcareous nannofossils $(245-50-1,107-109 \mathrm{~cm})$ underlies the $D$. barbadiensis Zone and the upper Eocene in Sample 245A-4-5, 115-117 cm.

The upper Eocene is characterized by nanno-bearing clay and nanno ooze, which are overlain by brown clay. The rate of deposition for the upper Eocene is approximately $7 \mathrm{~m} / \mathrm{m}$.y. A typical assemblage includes Reticulofenestra umbilica, $R$. bisecta, $R$. hillae, and Isthmolithus recurvus, with reduced numbers of Coccolithus pelagicus and C. formosus.

Site 239 (Table 3) $\left(21^{\circ} 17.67^{\prime} \mathrm{S}, 5^{\circ} 41.73^{\prime} \mathrm{E}\right.$; sonic depth $4971 \mathrm{~m}$ )

A total of 326 meters of sediment were penetrated at this site in the Southern Mascarene Basin. Sediments re- covered ranged in age from Cretaceous to Quaternary.

The primary purpose for sampling these sediments was to obtain Eocene nanno-bearing sediments not recovered at Site 245. A small section of clay-rich nanno chalk in Section 239-14-1 had been tentatively assigned to the Sphenolithus pseudoradians Zone by Müller, 1974). Unfortunately, no samples from this interval were available for our study and samples from adjacent intervals were barren.

Of the twelve samples examined from Cores 239-1419 , only one $(239-16-4,127-129 \mathrm{~cm})$ contained calcareous nannofossils. These belong to the Fasciculithus tympaniformis Zone. Preservation in this sample was very poor. Two other samples, 239-17-5, 52-54 cm and 239$19-1,55-57 \mathrm{~cm}$, contained only rims of placoliths.

\section{Site 240 (Table 3$)\left(30^{\circ} 29.28^{\prime} \mathrm{S}, 5^{\circ} 03.42\right.$ ' E; sonic depth $5082 \mathrm{~m}$ )}

Holes 240 and 240A were drilled at Site 240 in the Somali Basin, penetrating, respectively, 195 meters and 202 meters of sediment.

Sample 240A-3,CC has been well described by Bukry (1974, p. 637), who assigned it to his Campylosphaera eodela Subzone of the Discoaster multiradiatus Zone. Besides containing abundant specimens of the zonal markers, the sample contains common Sphenolithus an- 
Table 1B. Distribution of calcareous nannofossil species, Leg 25, Hole 245: Sample 245-62, 138-140 cm to Sample 245-12-1, 130-132 cm.

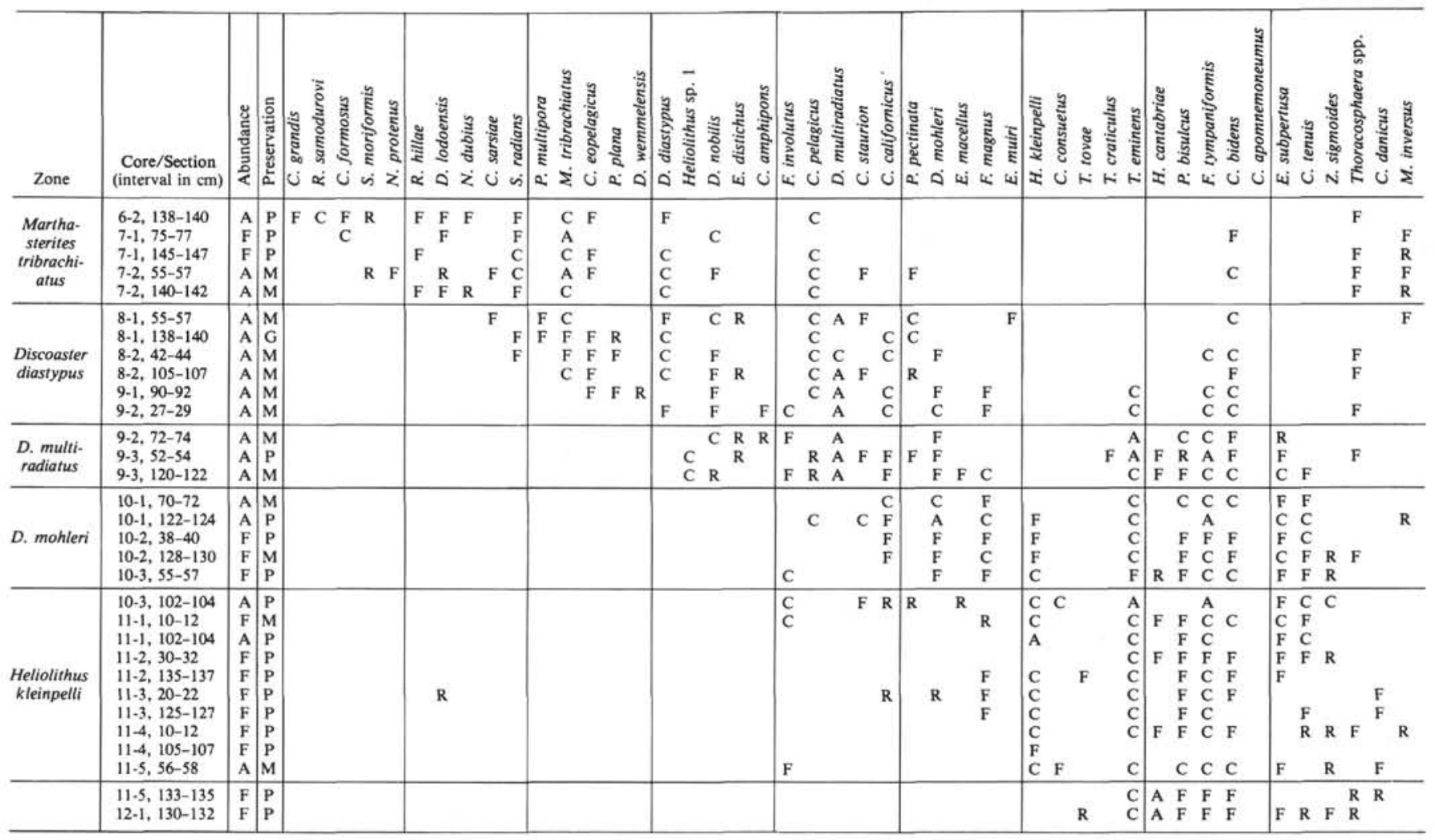

Note: For explanation of letters, see Table 1A. For genus names, see Appendix A.

Table 1C. Distribution of calcareous nannofossil species, Leg 25, Hole 245: Sample 245-12-22, 85-87 cm to Sample 245-15-1, 103-105 cm.

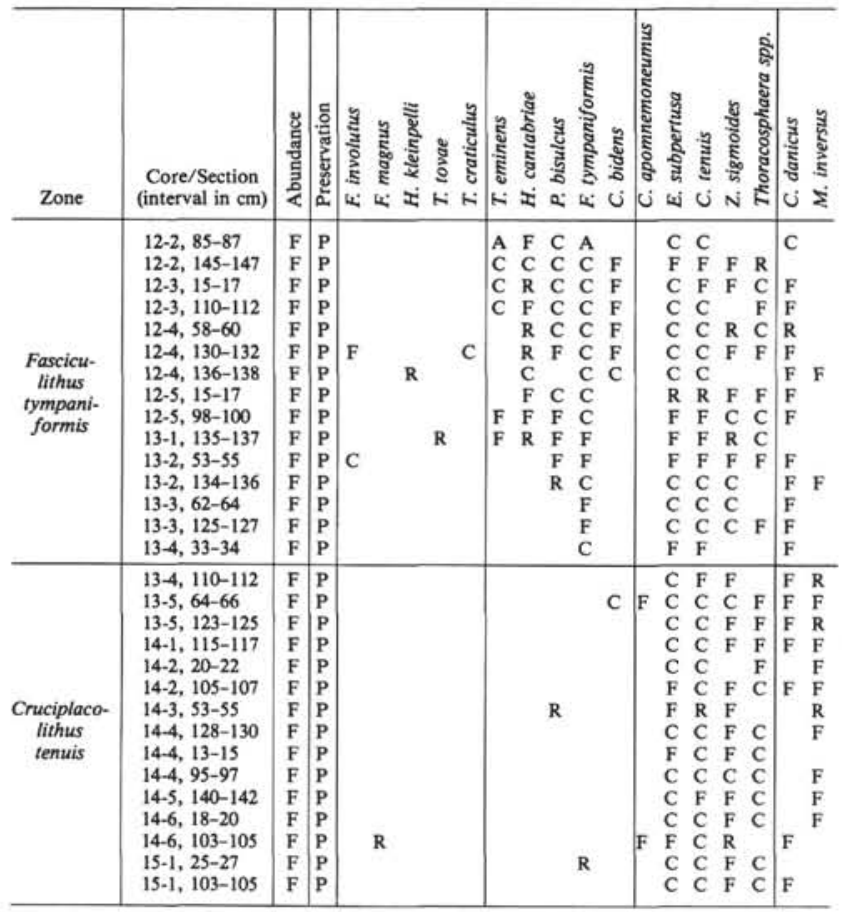

Note: For explanation of letters, see Table 1A. For genus names, see Appendix A. arrhopus, a species not reported in equivalent strata at Site 245 to the south.

Site 241 (Table 3) $\left(02^{\circ} 22.24^{\prime} \mathrm{S}, 44^{\circ} 40.77^{\prime} \mathrm{E}\right.$; sonic depth $4054 \mathrm{~m}$ )

Hole 241 penetrated 1174 meters of sediment on the East African continental rise. Sediments recovered range in age from early Turonian to Quaternary.

Sediments from Hole 241 were examined in order to compare coccolith assemblages at the Discoaster sublodoensis $/ D$. lodoensis Zone boundary with those from Site 245 . However, of the six samples obtained, only one (241-18-1, 102-104) contained calcareous nannofossils. The species present suggest that this sample could belong to the $D$. sublodoensis Zone as suggested by Müller (1974, p. 587). Preservation was poor and few species were present for comparison to Site 245 . No samples with calcareous nannofossils were obtained from the $D$. lodoensis Zone.

\section{SITE SUMMARIES: DSDP LEG $\mathbf{4 0}$}

Background information and detailed descriptions of cores from the following drill sites are given in the appropriate site chapters of the DSDP Leg 40 Initial Reports (Bolli, Ryan, et al., 1978). 
Table 2. Distribution of calcareous nannofossil species, Leg 25, Hole 245A.

\begin{tabular}{|c|c|c|c|c|c|c|c|c|c|c|c|c|c|c|c|}
\hline Zones & $\begin{array}{c}\text { Core/Section } \\
\text { (interval in cm) }\end{array}$ & 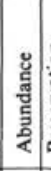 & 密. & 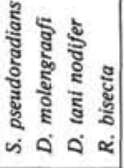 & 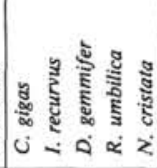 & 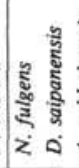 & & & 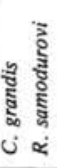 & 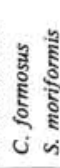 & $\begin{array}{l}\text { हैँ } \\
\text { के } \\
\text { zे }\end{array}$ & 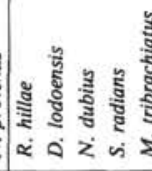 & 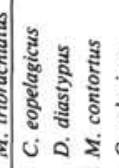 & &  \\
\hline $\begin{array}{l}\text { No zone } \\
\text { assigned }\end{array}$ & $\begin{array}{l}1-2,45-47 \\
1-6,85-86 \\
2-1,75-77 \\
\end{array}$ & & & Barren & & & & & & & & & & & \\
\hline $\begin{array}{l}\text { Discoaster } \\
\text { barbadi- } \\
\text { ensis }\end{array}$ & $\begin{array}{l}2-2,103-105 \\
2-3,15-17 \\
2-3,36-38 \\
2-4,45-47 \\
2-4,110-112 \\
2-5,66-68 \\
2-5,98-100 \\
2-6,50-52 \\
3-1,103-105 \\
3-2,40-42 \\
3-2,110-112 \\
3-3,123-125 \\
4-1,134-136 \\
4-2,18-20 \\
4-2,110-112 \\
4-3,8-10 \\
4-3,120-122 \\
4-4,42-44 \\
4-4,138-140 \\
4-5,62-64 \\
4-5,115-117 \\
\end{array}$ & 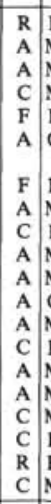 & 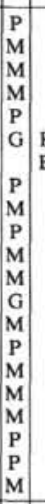 & 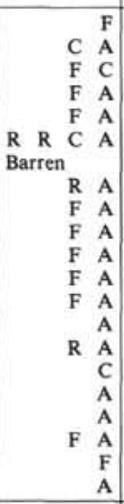 & 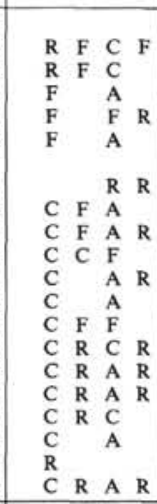 & $\begin{array}{ll} & \mathrm{R} \\
\mathrm{R} \\
\mathrm{R} \\
\mathrm{R} \\
\mathrm{R} \\
\mathrm{R} \\
\\
\\
\mathrm{F} \\
\mathrm{F} \\
\mathrm{F} \\
\mathrm{F} \\
\mathrm{R} \\
\mathrm{R} \\
\mathrm{R} \\
\mathrm{R} \\
\mathrm{F} \\
\mathrm{R}\end{array}$ & $\begin{array}{l}\mathrm{C} \\
\mathrm{F} \\
\mathrm{R} \\
\mathrm{R} \\
\mathrm{F} \\
\mathrm{R} \\
\mathrm{F} \\
\mathrm{F} \\
\mathrm{R} \\
\mathrm{C} \\
\mathrm{F} \\
\mathrm{F} \\
\mathrm{R} \\
\mathrm{R}\end{array}$ & 1 & $\begin{array}{ll}\mathrm{R} \\
\mathrm{R} \\
& \\
& \\
& \\
& \mathrm{R} \\
\mathrm{R} \\
\mathrm{F} \\
\mathrm{F} & \mathrm{F} \\
\mathrm{R} & \mathrm{F} \\
& \\
\mathrm{R} & \mathrm{F} \\
\end{array}$ & 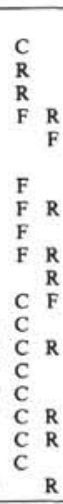 & ? & 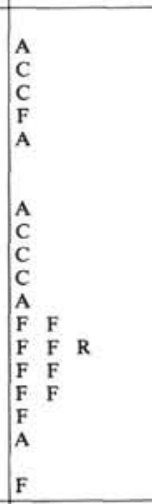 & 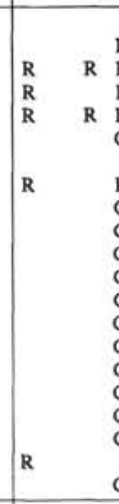 & $\begin{array}{l}\mathrm{F} \\
\mathrm{F} \\
\mathrm{F} \\
\mathrm{F} \\
\mathrm{C} \\
\mathrm{F} \\
\mathrm{C} \\
\mathrm{C} \\
\mathrm{C} \\
\mathrm{C} \\
\mathrm{C} \\
\mathrm{C} \\
\mathrm{C} \\
\mathrm{C} \\
\mathrm{C} \\
\mathrm{C} \\
\mathrm{C} \\
\mathrm{C}\end{array}$ & $\mathbf{R}$ \\
\hline $\begin{array}{l}\text { Reticulo- } \\
\text { fenestra } \\
\text { umbilica }\end{array}$ & $\begin{array}{l}5-1,107-109 \\
5-2,123-125 \\
5-3,123-125 \\
5-4,73-75 \\
5-4,120-122 \\
\end{array}$ & $\begin{array}{l}\mathrm{F} \\
\mathrm{R} \\
\mathrm{F} \\
\mathrm{F}\end{array}$ & \begin{tabular}{|l|l} 
& $\mathrm{P}$ \\
$\mathrm{P}$ & \\
$\mathrm{P}$ & \\
$\mathrm{P}$ & \\
$\mathrm{P}$ & \\
\end{tabular} & Barren & $\begin{array}{l}\mathrm{F} \\
\mathrm{R}\end{array}$ & $F$ & $\begin{array}{l}\mathrm{F} \\
\mathrm{A} \\
\mathrm{C} \\
\mathrm{F} \\
\end{array}$ & & & F & & R & & $\begin{array}{l}\mathrm{F} \\
\mathrm{F}\end{array}$ & \\
\hline $\begin{array}{l}\text { Nanno- } \\
\text { tetrina } \\
\text { fulgens }\end{array}$ & $\begin{array}{l}6-1,104-106 \\
6-1,140-142 \\
6-2,31-33 \\
6-2,138-140 \\
6-3,55-57 \\
6-3,144-146\end{array}$ & $\begin{array}{l:l}\mathrm{F} & \\
\mathrm{R} & \\
\mathrm{F} & \\
\mathrm{F} & \\
\mathrm{F} & \\
\mathrm{F} & \end{array}$ & \begin{tabular}{|l|}
$\mathrm{P}$ \\
$\mathrm{P}$ \\
$\mathrm{P}$ \\
$\mathrm{P}$ \\
$\mathrm{P}$ \\
$\mathrm{P}$ \\
\end{tabular} & & $\begin{array}{rl} & F \\
& C \\
R & C \\
& C\end{array}$ & $\begin{array}{ll} & R \\
\text { R } & \text { C } \\
F & \end{array}$ & $\begin{array}{l}\text { C } \\
\text { F } \\
\text { F } \\
\text { C } \\
\text { C } \\
\text { C }\end{array}$ & & $\begin{array}{ll}R & F \\
R & C \\
C & F \\
R & \end{array}$ & c & & $\begin{array}{l}\text { C } \\
\text { F }\end{array}$ & $\begin{array}{lll}R & & \\
R & F & \\
R & F & R \\
R & \end{array}$ & $\begin{array}{l}\mathrm{F} \\
\mathrm{F} \\
\mathrm{C} \\
\mathrm{F}\end{array}$ & R \\
\hline $\begin{array}{c}\text { Discoaster } \\
\text { sublodo- } \\
\text { ensis }\end{array}$ & $\begin{array}{l}7-1,135-137 \\
7-2,115-117 \\
7-3,15-17 \\
7-3,133-135 \\
7-4,42-44\end{array}$ & 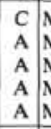 & \begin{tabular}{|c|}
$\mathrm{M}$ \\
$\mathrm{M}$ \\
$\mathrm{M}$ \\
$\mathrm{M}$ \\
$\mathrm{M}$ \\
\end{tabular} & & F & 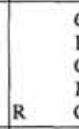 & $\begin{array}{ll}C & \mathrm{C} \\
\mathrm{F} & \mathrm{C} \\
\mathrm{C} & \mathrm{C} \\
\mathrm{F} & \mathrm{C} \\
\mathrm{C} & \mathrm{C}\end{array}$ & & $\begin{array}{ll}C & \mathrm{~F} \\
\mathrm{~A} & \mathrm{~A} \\
\mathrm{C} & \mathrm{C} \\
\mathrm{C} & \mathrm{C} \\
\mathrm{C} & \mathrm{C}\end{array}$ & $\begin{array}{l}\text { C } \\
\text { A } \\
\text { C } \\
\text { C } \\
\text { C }\end{array}$ & $\begin{array}{l}\mathrm{C} \\
\mathrm{C} \\
\mathrm{C} \\
\mathrm{C} \\
\mathrm{C}\end{array}$ & 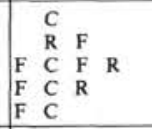 & $\begin{array}{llllll} & & & \\
R & F & R & \\
F & & & \\
F & & & \\
R & & & \\
\end{array}$ & $\begin{array}{l}\mathrm{C} \\
\mathrm{C} \\
\mathrm{F} \\
\mathrm{F} \\
\mathrm{F} \\
\end{array}$ & R R \\
\hline $\begin{array}{l}\text { D. lodo- } \\
\text { ensis }\end{array}$ & $\begin{array}{l}7-4,105-107 \\
7-5,50-52 \\
7-5,130-132 \\
7-6,54-56 \\
7-6,133-135\end{array}$ & $\begin{array}{l:l}\text { A } & \\
\text { A } & \\
\text { A } & \\
\text { F } & \end{array}$ & \begin{tabular}{|l|}
$\mathrm{M}$ \\
$\mathrm{M}$ \\
$\mathrm{M}$ \\
$\mathrm{M}$ \\
$\mathrm{P}$
\end{tabular} & & & & $\begin{array}{l}\mathrm{C} \\
\mathrm{C} \\
\mathrm{C} \\
\mathrm{A} \\
\mathrm{F}\end{array}$ & & $\begin{array}{ll}\mathrm{C} & \mathrm{C} \\
\mathrm{C} & \mathrm{C} \\
\mathrm{C} & \mathrm{C} \\
\mathrm{C} & \mathrm{C}\end{array}$ & $\begin{array}{l}\mathrm{C} \\
\mathrm{C} \\
\mathrm{C} \\
\mathrm{A} \\
\mathrm{F}\end{array}$ & $\begin{array}{l}\mathrm{c} \\
\mathrm{c} \\
\mathrm{C}\end{array}$ & $\begin{array}{llll}\mathrm{F} & \mathrm{C} & & \\
\mathrm{F} & \mathrm{C} & \mathrm{R} & \\
\mathrm{F} & \mathrm{C} & \mathrm{R} & \\
& \mathrm{A} & \mathrm{C} & \mathrm{R} \\
\mathrm{R} & \mathrm{F} & & \end{array}$ & \begin{tabular}{|l}
$\mathrm{R}$ \\
$\mathrm{R}$ \\
$\mathrm{F}$ \\
$\mathrm{F}$
\end{tabular} & $\begin{array}{l}F \\
F \\
F \\
C \quad R \\
F\end{array}$ & R $R$ \\
\hline
\end{tabular}

Note: For explanation of letters, see Table 1A. For genus names, see Appendix A.

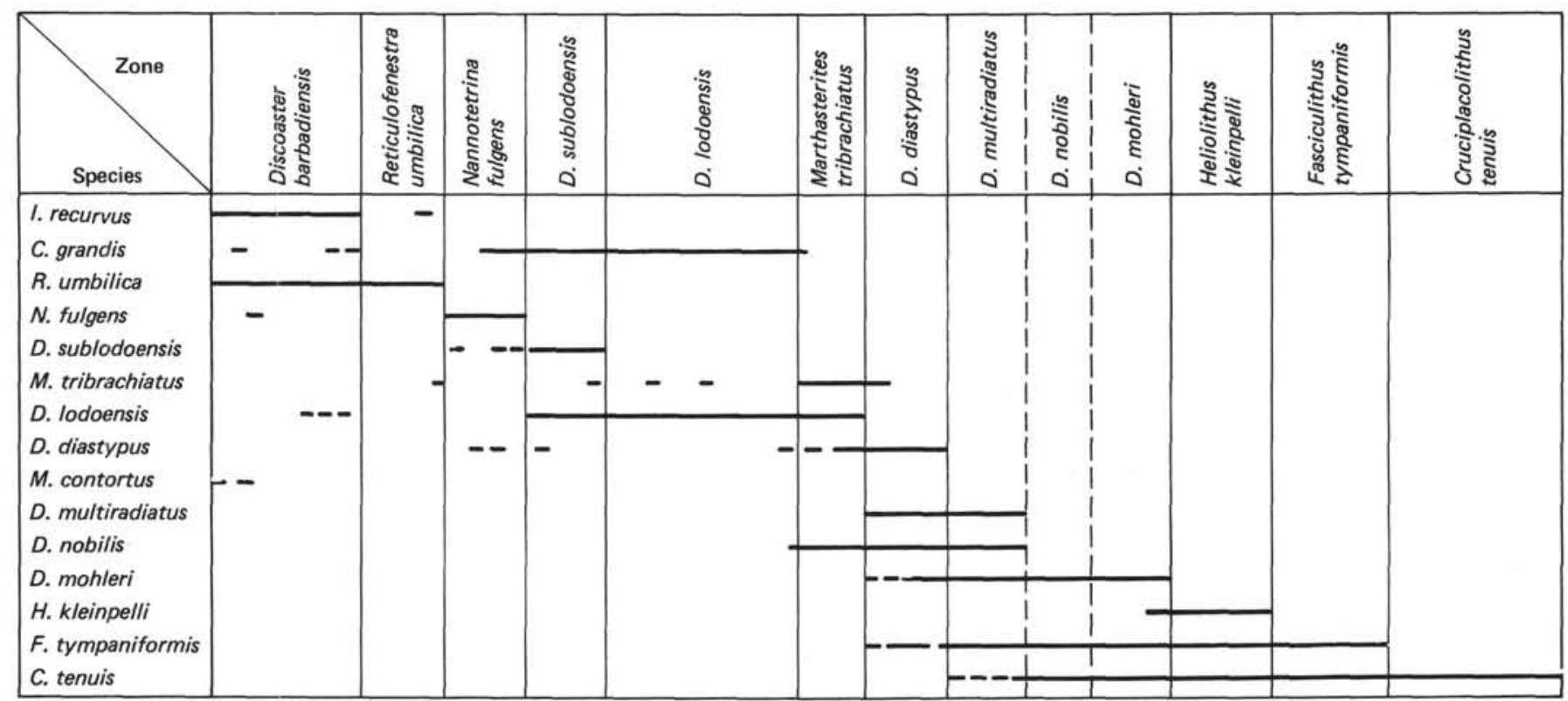

Figure 4. Selected calcareous nannofossil species and ranges, Leg 25, Holes 245 and 245A. (Genus names in Appendix A.) 
Table 3. Distribution of calcareous nannofossil species, Leg 25, Holes 239, 240, 241.

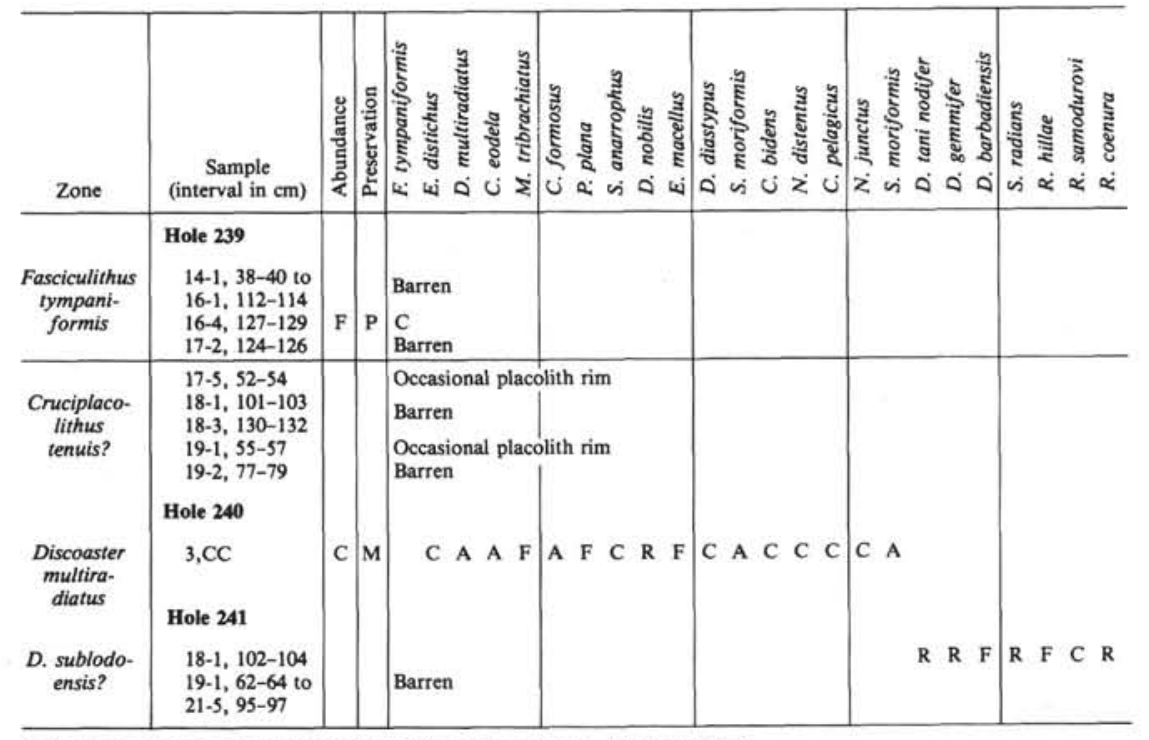

Note: For explanation of letters see Table 1A. For genus names, see Appendix A.

Site 360 (Table 4, Fig. 5) $\left(3^{\circ} 50.75^{\prime} \mathrm{S}, 1^{\circ} 05.79^{\prime} \mathrm{E}\right.$; sonic depth $2949 \mathrm{~m}$ )

A total of 840 meters of sediment were penetrated at this site, located midway down the continental rise of Southwest Africa. Sediments recovered range in age from Eocene to Pliocene.

Site 360 bottomed in sediments from the Nannotetrina fulgens Zone. Middle Eocene lithologies are predominantly marly nannofossil chalks with some interspersed calcareous claystones and nannofossil chalk. Preservation is poor to moderate with one exception (good preservation in Sample 360-50-1, 122-124 cm). The rate of deposition is high, approximately $44.0 \mathrm{~m} / \mathrm{m} . \mathrm{y}$. As at Site 245, the Discoaster-Reticulofenestra-Coccolithus assemblage (Haq and Lohmann, 1976) appears typical. However, better preservation and/or cooler temperatures have resulted in a higher percentage of Chiasmolithus.

The upper Eocene is characterized by marly nannofossil chalk with poor to good coccolith preservation. The rate of deposition is approximately $15 \mathrm{~m} / \mathrm{m} . \mathrm{y}$. As at Site 245 , a typical assemblage includes Isthmolithus recurvus and reticulofenestrids, but a decrease in the percentage of Coccolithus pelagicus and C. formosus.

Using the last occurrence of $D$. saipanensis to mark the Eocene/Oligocene boundary, the top of the Discoaster barbadiensis Zone is placed above Sample 360-36-2, 44-46 cm.

\section{Site 361 (Table 5, Fig. 6) $\left(3^{\circ} 03.97^{\prime} \mathrm{S}, 1^{\circ} 26.91^{\prime} \mathrm{E}\right.$; sonic depth $4549 \mathrm{~m}$ )}

A total of 1314 meters of sediment was penetrated at Site 361 , which is located at the base of the Southwest African continental rise. The sediments recovered range from lower Aptian to upper Barremian to upper Eocene.

Large coring gaps at Site $\mathbf{3 6 1}$ prevent accurate determination of zonal boundaries and sedimentation rates, and make characterization of assemblages untenable. The oldest Paleocene nannofossil-bearing sediments examined were from the Cruciplacolithus tenuis Zone (361$10-1,121-123 \mathrm{~cm}$ ) of the lower Paleocene. The preservation in this marly nannofossil chalk is very poor, with Markalius inversus and $C$. tenuis being the only taxa present.

The upper Paleocene is represented by the Discoaster nobilis Zone (361-9-3, 91-93 cm) and the D. multiradiatus Zone (361-9-2, 51-53 cm) in a marly nannofossil chalk. Nannofossil assemblages from the $D$. nobilis Zone are poorly preserved with $D$. nobilis and $D$. mohleri the most common species present. Preservation of coccoliths in the D. multiradiatus Zone is also poor; the most common taxa include D. multiradiatus, Fasciculithus tympaniformis, and species of the genus Heliolithus. Heliolithus sp. 1, as used in this study, was previously described in Wise and Wind (1977) and referred to by Müller (1974) and Bukry (1974) as various combinations of Cyclolithus? robustus Bramlette and Sullivan, 1961. Although Heliolithus sp. 1 is resistant to solution and is restricted to the $D$. multiradiatus Zone at Sites 245 and 361 , it was found only in the $H$. universus Zone (Wise and Wind, 1977) immediately preceding the $D$. multiradiatus Zone at Hole 327A on the Falkland Plateau.

The lower Eocene is represented by sediments recovered in Core 361-8 and consists of marly nannofossil ooze and nannofossil chalk. Preservation is poor in these sediments but the presence of Marthasterites contortus and $D$. diastypus place this core in the $D$. diastypus Zone. The most common taxa are $D$. multiradiatus, $F$. tympaniformis, and $D$. diastypus.

The middle to upper Eocene is represented by Cores 361-1, and 361-4-7. Lithologies include marly nannofossil ooze, calcareous mud, and mud. Coccoliths in Cores 361-4-7 have good preservation and fall within the $D$. sublodoensis Zone. Although the upper and lower boundaries of this zone are not discernible in these 
Table 4. Distribution of calcareous nannofossil species, Leg 40, Hole 360.

\begin{tabular}{|c|c|c|c|c|c|c|c|c|c|c|c|c|c|c|c|c|c|c|c|c|c|}
\hline Zone & $\begin{array}{l}\text { Core/Section } \\
\text { (interval in } \mathrm{cm} \text { ) }\end{array}$ & 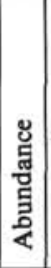 & 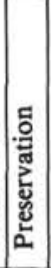 & 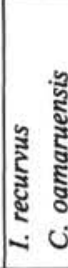 & 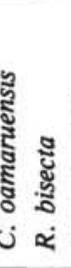 & 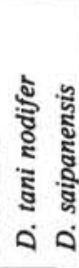 & 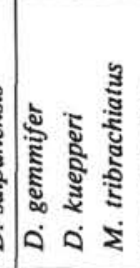 & 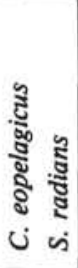 & 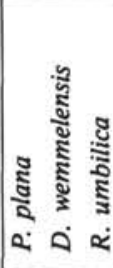 & 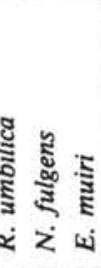 & 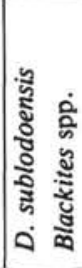 & 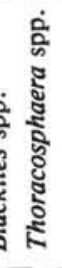 & ن & 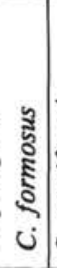 & 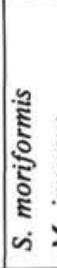 & 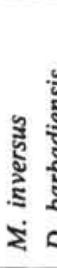 & 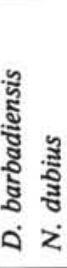 & 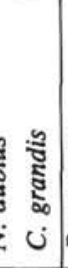 & 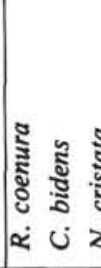 & 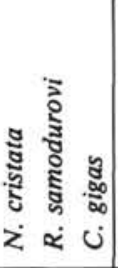 & 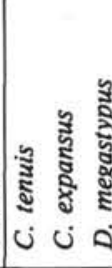 \\
\hline $\begin{array}{c}\text { Discoaster } \\
\text { barba- } \\
\text { diensis }\end{array}$ & $\begin{array}{l}36-2,44-46 \\
36-4,103-105 \\
37-1,135-137 \\
37-2,106-108 \\
38-1,77-78 \\
39-1,126-128 \\
\end{array}$ & $\begin{array}{l}\mathrm{C} \\
\mathrm{F} \\
\mathrm{C} \\
\mathrm{C} \\
\mathrm{C} \\
\mathrm{C}\end{array}$ & \begin{tabular}{|l|}
$\mathrm{M}$ \\
$\mathrm{P}$ \\
$\mathrm{P}$ \\
$\mathrm{P}$ \\
$\mathrm{P}$ \\
$\mathrm{P}$ \\
\end{tabular} & $\begin{array}{ll}\text { A } & \text { A } \\
\text { C } & \\
\text { C } & \text { F } \\
\text { C } & \\
& \text { F } \\
\text { F } & \text { F } \\
\end{array}$ & $\begin{array}{ll}\mathrm{A} & \mathrm{A} \\
& \mathrm{A} \\
\mathrm{F} & \mathrm{A} \\
& \mathrm{C} \\
\mathrm{F} & \mathrm{A} \\
\mathrm{F} & \mathrm{C}\end{array}$ & $\begin{array}{ll}\mathrm{C} \\
\mathrm{C} \\
\mathrm{F} \\
\mathrm{C} \\
\mathrm{F} \\
\mathrm{F}\end{array}$ & & $\begin{array}{l}\mathrm{F} \\
\mathrm{F} \\
\mathrm{R}\end{array}$ & & $\begin{array}{l}\mathrm{C} \\
\mathrm{A} \\
\mathrm{C}\end{array}$ & $\mathbf{R}$ & $\begin{array}{l}\mathrm{F} \\
\mathrm{R} \\
\end{array}$ & $\begin{array}{l}\text { A } \\
\text { F } \\
\text { C } \\
\text { F } \\
\text { F } \\
\text { A }\end{array}$ & $\begin{array}{l}\mathrm{C} \\
\mathrm{C} \\
\mathrm{C} \\
\mathrm{F} \\
\mathrm{C} \\
\mathrm{A}\end{array}$ & F & F & $\begin{array}{l}F \\
F \\
F\end{array}$ & & & & \\
\hline
\end{tabular}

Note: For explanation of letters, see Table 1A. For genus names, see Appendix B.

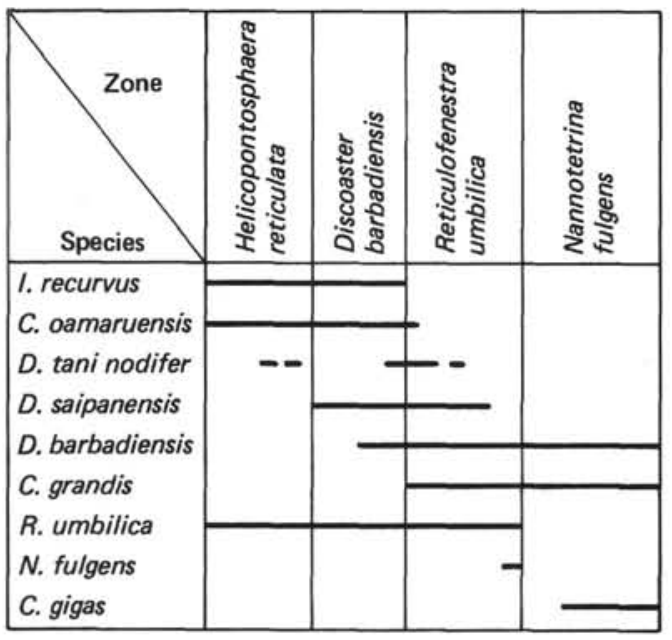

Figure 5. Selected calcareous nannofossil species and ranges, Leg 40, Hole 360. (Genus names in Appendix B.)

cores, the material assigned to this zone indicates a rate of deposition of at least $66 \mathrm{~m} / \mathrm{m}$.y.

Preservation in Core $361-1$ is very poor. In the samples available to us, only Reticulofenestra bisecta and $R$. umbilica were present in Sample 361-1-6, 56-58 cm, and $R$. bisecta in Sample 361-1-1, 141-143 cm. Cores 361-2 and 361-3 were barren of calcareous nannofossils. On the basis of more detailed sampling, Proto Decima et al. (1978) were able to place Cores $361-1$ and $361-2$ in the upper Eocene.

\section{Ratios of Taxa}

To assist in paleoecological analyses, ratios of Discoaster to Chiasmolithus and of Discoaster to placoliths were determined for selected samples which showed varying degrees of preservation at different sites. These results are given in Table 6 .

\section{ANALYSIS AND DISCUSSION}

Sediments recovered from DSDP Leg 25, Holes 245 and $245 \mathrm{~A}$ provide a nearly complete record of the $\mathrm{Pa}$ leocene and Eocene; only the lowermost Paleocene and uppermost Eocene are missing. A few meters of sediment were not recovered at the bottom of Hole 245 and a high CCD in the late Eocene prevented preservation of calcareous nannofossils in the uppermost Eocene sediments (245A-1-2, 45-47 cm; 245A-1-6, 85-87 cm; 245A2-1, 75-77 cm are barren of coccoliths). A high CCD in 
Table 5. Distribution of calcareous nannofossil species, Leg 40, Hole 361.

\begin{tabular}{|c|c|c|c|c|c|c|c|c|c|c|c|c|c|}
\hline Zones & $\begin{array}{c}\text { Core/Section } \\
\text { (interval in } \mathrm{cm} \text { ) }\end{array}$ & & 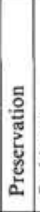 & 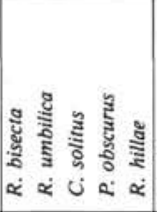 & 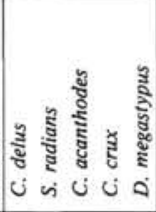 & 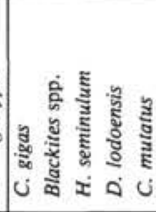 & 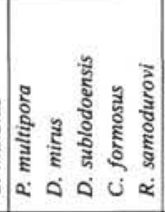 & 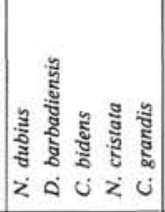 & 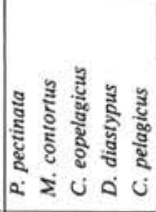 & 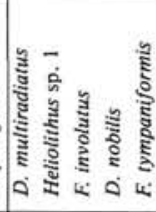 & 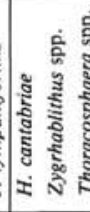 & 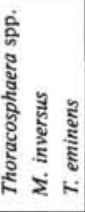 & 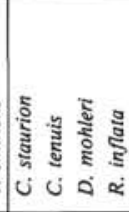 \\
\hline $\begin{array}{l}\text { No zone } \\
\text { assigned }\end{array}$ & $\begin{array}{l}1-1,141-143 \\
1-6,56-58 \\
2-2,35-37 \\
3-6,102-104\end{array}$ & $\begin{array}{l}\mathrm{R} \\
\mathrm{R}\end{array}$ & $\begin{array}{l}\mathrm{P} \\
\mathrm{P}\end{array}$ & $\begin{array}{l}\text { R } \\
\text { F } \\
\text { Barren }\end{array}$ & & & & & & & & & \\
\hline $\begin{array}{c}\text { Discoaster } \\
\text { sublodoensis }\end{array}$ & $\begin{array}{l}4-1,137-139 \\
5-3,96-98 \\
5-5,125-127 \\
6-1,141-143 \\
6-3,91-93 \\
7-1,111-113\end{array}$ & \begin{tabular}{l|l|l}
$\mathrm{A}$ & \\
$\mathrm{A}$ & \\
$\mathrm{C}$ & \\
$\mathrm{A}$ & \\
$\mathrm{C}$ & \\
$\mathrm{A}$ & &
\end{tabular} & \begin{tabular}{|l|}
$G$ \\
$G$ \\
$G$ \\
$G$ \\
$G$ \\
$G$ \\
\end{tabular} & 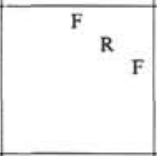 & $F \subset F^{R}{ }^{R}$ & $\begin{array}{lllll} & \text { C } & & & \\
\text { F } & \text { C } & R & \\
F & & C & C \\
& F & F & R & R\end{array}$ &  & $\begin{array}{|lllll|}\mathrm{A} & \mathrm{A} & \mathrm{A} & \mathrm{C} & \mathrm{C} \\
\mathrm{C} & \mathrm{A} & \mathrm{A} & \mathrm{A} & \mathrm{C} \\
\mathrm{F} & \mathrm{F} & & & \mathrm{C} \\
\mathrm{A} & \mathrm{C} & \mathrm{A} & \mathrm{F} & \\
\mathrm{A} & \mathrm{R} & \mathrm{A} & \mathrm{F} & \mathrm{C} \\
\mathrm{A} & \mathrm{A} & \mathrm{A} & \mathrm{F} & \mathrm{C} \\
\end{array}$ & $\begin{array}{lll}\mathrm{R} & \mathrm{R} & \mathrm{R} \\
\mathrm{R} & \mathrm{C} & \mathrm{F} \\
\mathrm{R} & \mathrm{C} & \\
& \mathrm{C} & \\
& \mathrm{F} & \mathrm{C} \\
& \mathrm{F} & \mathrm{C}\end{array}$ & & & $\begin{array}{ll}R & R \\
R & R \\
& R\end{array}$ & \\
\hline D. diastypus & $\begin{array}{l}8-1,131-133 \\
8-6,101-103\end{array}$ & $\begin{array}{l}\mathrm{C} \\
\mathrm{F} \\
\end{array}$ & \begin{tabular}{|l|}
$\mathrm{P}$ \\
$\mathrm{P}$ \\
\end{tabular} & & & & & & 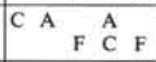 & $\begin{array}{ll}\mathrm{A} & \mathrm{C} \\
\mathrm{A} & \mathrm{C}\end{array}$ & & & $\mathrm{F}$ \\
\hline D. multiradiatus & $9-2,51-53$ & c & $P$ & & & & & & $\mathrm{~F}$ & A A F $F$ C A & C & & \\
\hline D. nobilis & $9-3,91-93$ & $F$ & $\mathrm{P}$ & & & & & & & C F & F R R & R $\quad F$ & R $\quad$ C \\
\hline $\begin{array}{l}\text { Cruciplacolithus } \\
\text { tenuis }\end{array}$ & $10-1,121-123$ & R & $P$ & & & & & & & & & $\mathrm{~F}$ & $\mathrm{~F}$ \\
\hline
\end{tabular}

Note: For explanation of letters, see Table 1A. For genus names, see Appendix B.

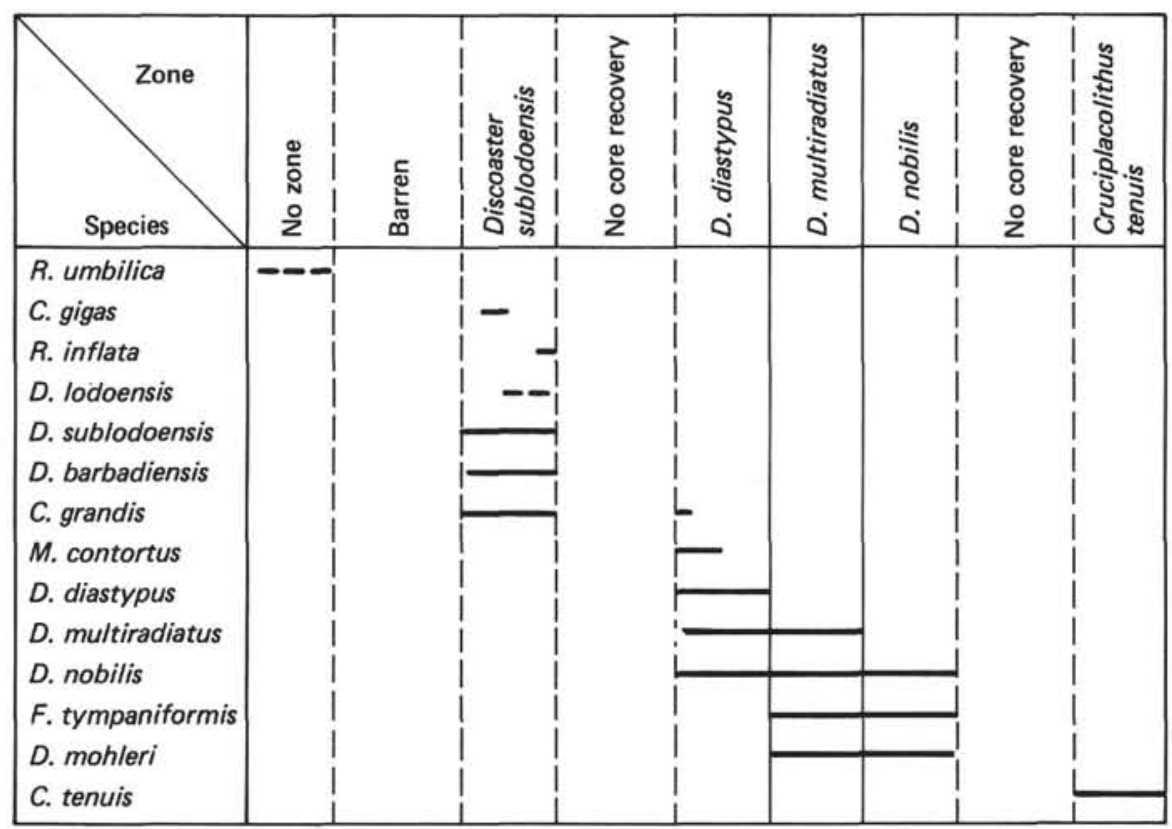

Figure 6. Selected calcareous nannofossil species and ranges, Leg 40, Hole 361. (Genus names in Appendix B.)

the late Eocene is also recorded at Site 239 (See Table 3). Samples from Core 239-14, (239-14-1, 38-40 cm; 23914-2, 107-109 cm), dated as the Sphenolithus pseudoradians Zone (late Eocene) in the Initial Reports for Leg 25 , were barren of nannofossils.

The CCD rose above the site of deposition during two brief intervals in the middle to late Eocene at Site 245 (Fig. 7). The first is recorded at the Reticulofenestra umbilica/Discoaster barbadiensis Zone boundary (245A5-1, 107-109 cm, barren of nannofossils). The second fluctuation occurred in the middle upper Eocene (245A$2-5,98-100 \mathrm{~cm}$, barren of nannofossils).

Sites 360 and 361 also had relatively complete sedimentary sequences through the Paleocene and Eocene
(Bolli, Ryan, et al., 1978). Unfortunately, coring was not as continuous at any of these sites. Cores from Site 360 bottomed in sediments of the Nannotetrina fulgens Zone and include an excellent nannofossil sequence through the upper Eocene and into the lower Oligocene that is uninterrupted by dissolution hiatuses.

Coring was not as continuous at Site 361. A hiatus in calcareous deposition was encountered in Samples 3612-2, 35-37 cm and 361-3-6, 102-104 cm (Fig. 6).

The absence of many weakly resistant species (e.g., Rhabdosphaera inflata, Sphenolithus pseudoradians, Isthmolithus recurvus) in different cores is attributed to dissolution, especially where preservation was poor (throughout most of the Paleocene and Eocene sediment- 
Table 6. Selected samples showing varying degrees of preservation, analyzed for the Discoaster/Chiasmolithus (Disc./ Chias.) ratio and the Discoaster/placolith (Disc./plac.) ratio from Holes 360, 361, 245A, and 245 .

\begin{tabular}{cccc}
\hline Sample & $\begin{array}{c}\text { Preserva- } \\
\text { vation }\end{array}$ & $\begin{array}{c}\text { Disc./Chias. } \\
\text { (interval in cm) }\end{array}$ & $\begin{array}{c}\text { Disc./plac. } \\
\text { ratio }\end{array}$
\end{tabular}

Hole 360

$\begin{array}{llll}34-4,100-102 & \mathrm{G} & 1 / 221 & 0.01 / 1 \\ 36-2,44-46 & \mathrm{M} & 200^{+} / 1 & 0.02 / 1 \\ 37-2,106-108 & \mathrm{P} & 200^{+} / 1 & 0.04 / 1 \\ 39-3,56-58 & \mathrm{M} & 3.81 / 1 & 0.07 / 1 \\ 40-1,106-107 & \mathrm{P} & 1.22 / 1 & 0.05 / 1 \\ 41-2,100-102 & \mathrm{M} & 3.47 / 1 & 0.12 / 1 \\ 42-2,79-81 & \mathrm{P} & 11.5 / 1 & 0.08 / 1 \\ 45-1,99-101 & \mathrm{M} & 0.4 / 1 & 0.07 / 1 \\ 46-1,132-134 & \mathrm{P} & 3.25 / 1 & 0.21 / 1 \\ 48-5,70-71 & \mathrm{M} & 0.49 / 1 & 0.07 / 1 \\ 50-1,122-124 & \mathrm{G} & 0.45 / 1 & 0.07 / 1\end{array}$

Hole 361

$\begin{array}{llll}1-1,141-143 & \mathrm{P} & 0 / 0 & 200^{+} / 1 \\ 1-6,56-58 & \mathrm{P} & 0 / 0 & 200^{+} / 1 \\ 5-3,96-98 & \mathrm{G} & 0.38 / 1 & 0.04 / 1 \\ 6-3,91-93 & \mathrm{G} & 0.13 / 1 & 0.03 / 1 \\ 8-6,101-103 & \mathrm{P} & 1.53 / 1 & 1.09 / 1\end{array}$

Hole $245 \mathrm{~A}$

$2-3,36-38$
$2-4,110-112$
$2-6,50-52$
$3-2,40-42$
$3-2,110-112$
$4-2,18-20$
$4-2,110-112$
$4-3,8-10$
$4-4,42-44$
$4-5,115-117$
$5-2,123-125$
$6-1,140-142$
$7-1,135-137$
$7-5,130-132$
$7-6,133-135$

$\begin{array}{lll}\mathrm{M} & 14.5 / 1 & 0.03 / 1 \\ \mathrm{P} & 1 / 200^{+} & 0.05 / 1 \\ \mathrm{M} & 1 / 200^{+} & 0.07 / 1 \\ \mathrm{P} & 53 / 1 & 0.02 / 1 \\ \mathrm{P} & 94 / 1 & 0.03 / 1 \\ \mathrm{M} & 36 / 1 & 0.02 / 1 \\ \mathrm{P} & 88 / 1 & 0.03 / 1 \\ \mathrm{M} & 79 / 1 & 0.03 / 1 \\ \mathrm{M} & 1 / 200^{+} & 0.01 / 1 \\ \mathrm{M} & 31 / 1 & 0.04 / 1 \\ \mathrm{P} & 1 / 200^{+} & 0.36 / 1 \\ \mathrm{P} & 1 / 200^{+} & 0.50 / 1 \\ \mathrm{M} & 2.53 / 1 & 0.26 / 1 \\ \mathrm{M} & 7.88 / 1 & 0.35 / 1 \\ \mathrm{P} & 28.1 / 1 & 0.33 / 1\end{array}$

Hole 245

\begin{tabular}{lcll}
$3-1,80-82$ & $\mathrm{P}$ & $1 / 200^{+}$ & $0.40 / 1$ \\
$3-5,91-92$ & $\mathrm{G}$ & $0.81 / 1$ & $0.05 / 1$ \\
$4-3,135-137$ & $\mathrm{M}$ & $4.33 / 1$ & $0.19 / 1$ \\
$4-6,138-140$ & $\mathrm{P}$ & $21.8 / 1$ & $0.30 / 1$ \\
$5-1,52-54$ & $\mathrm{M}$ & $9.14 / 1$ & $0.46 / 1$ \\
$5-4,22-24$ & $\mathrm{M}$ & $12.3 / 1$ & $0.26 / 1$ \\
$5-4,123-125$ & $\mathrm{P}$ & $14.1 / 1$ & $0.18 / 1$ \\
$5-6,105-107$ & $\mathrm{M}$ & $24.6 / 1$ & $0.33 / 1$ \\
$6-1,108-110$ & $\mathrm{P}$ & $10.8 / 1$ & $0.18 / 1$ \\
$7-2,140-142$ & $\mathrm{M}$ & $14.0 / 1$ & $0.33 / 1$ \\
$8-1,138-140$ & $\mathrm{G}$ & $2.05 / 1$ & $0.09 / 1$ \\
$8-2,42-44$ & $\mathrm{M}$ & $8.00 / 1$ & $0.06 / 1$ \\
$9-1,90-92$ & $\mathrm{M}$ & $1.62 / 1$ & $0.09 / 1$ \\
\hline
\end{tabular}

ary sections). However, some obvious differences exist between the coccolith assemblages at Site 245 and those of Sites 360 and 361 .

Eocene calcareous nannofossil assemblages at Sites 360 and 361 contain a greater abundance and higher percentage of cool-water species than do assemblages from Site 245. The cool-water species Neococcolithus dubius is much more common in lower to middle Eocene samples from Leg 40 than those of comparable age from Leg 25 . The same is true for the middle and late Eocene nannofossils $I$. recurvus and $R$. bisecta. The fairly resistant, cool-water species, Chiasmolithus oamaruensis (late Eocene) was observed only in samples from Site 360 . The warm-water species $D$. barbadiensis, which becomes extinct at the Eocene/Oligocene boundary in the tropics, disappears prematurely at Site 360 . Too few samples were obtained for analysis of nannofossil assemblages from the Paleocene at Sites 360 and 361 .

At Site 245, warm-water species seem to predominate until the late Eocene where $I$. recurvus and $R$. bisecta become quite numerous in the $D$. barbadiensis Zone. However, the warm-water species $D$. barbadiensis and $D$. saipanensis are present up until the rise of the CCD above the site of deposition between Samples 245-2-2, $103-105 \mathrm{~cm}$ and $245 \mathrm{~A}-2-1,75-77 \mathrm{~cm}$ (Table 2), which produced a hiatus in carbonate deposition. $R$. bisecta is the sole species present in Samples 245A-2-2, 103-105 $\mathrm{cm}$ and 361-1-1, 141-143 cm.

Shifts in Paleogene nannoflora at Site 245 are compared with the results of Haq and Lohmann (1976). A high-latitude assemblage characterized by common Prinsius bisulcus is recorded at Site 245 in the Fasciculithus tympaniformis Zone, 59-58 Ma (Table 1). Although the species $P$. bisulcus extends beyond this zone (Table 1), it is never quite so abundant. Haq and Lohmann's midlatitude Ericsonia subpertusa assemblage disappears during the $D$. multiradiatus Zone (54 Ma).

Although Haq and Lohmann (1976) report several shifts of nannoflora assemblages during the Eocene, their mid-latitude Discoaster and $R$. umbilica-R. bisecta-Coccolithus pelagicus assemblages seem to be quite similar to those found throughout the Eocene at Sites 245,360 , and 361 .

An attempt was made to use the Discoaster/Chiasmolithus ratio (Fig. 7) to determine average surface water temperatures (Bukry, 1973b). Bukry (1974) describes several paleotemperature events utilizing this technique in samples from Site 242. We compared the Discoaster/ Chiasmolithus ratio to the Discoaster/placolith ratio (Table 6) and using samples showing preservational change (example: moderate to poor), it was observed that as the Discoaster/Chiasmolithus ratio increased, there was a corresponding, though not necessarily equal, increase in the Discoaster/placolith ratio.

Dissolution and overgrowth play an important role in the preservation of calcareous nannofossils in the cores examined. Coccoliths in every sample examined were at least partially dissolved; some samples were completely devoid of coccoliths as a result of dissolution. Paleocene assemblages were typically heavily etched, whereas many Eocene samples showed heavy overgrowths.

The intensity of dissolution may be determined by the percentage of discoasters in a sample. Ramsay (1972) believed the percentage of discoasters increases with depth. However, even deep-water sediments may be well preserved during periods of rapid deposition. Figure 8 suggests that the Discoaster/placolith ratio is more nearly aligned with the proximity of the CCD than with the depth of deposition. 


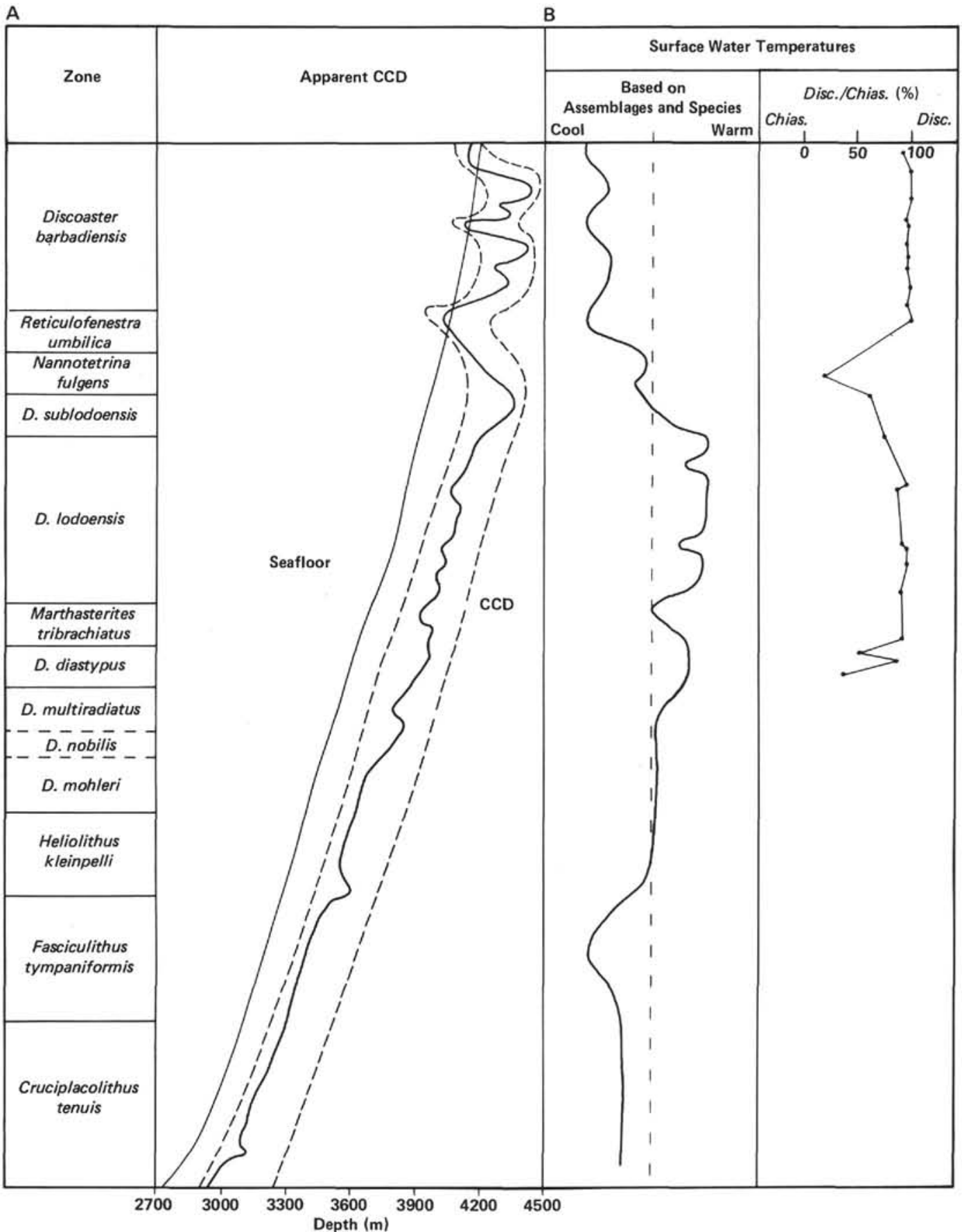

Figure 7. A. Paleodepth and CCD through time at Site 245 according to Berger's (1972) back-tracking method. B. Speculations on generalized surface water temperatures (cool vs. warm) as determined by a qualitative assessment of assemblages/species and the Discoaster/Chiasmolithus ratio.

If dissolution presents many problems to biostratigraphy, overgrowths may be even more frustrating. Species within the genera Nannotetrina and Marthasterites are especially prone to overgrowths and differentiating among them becomes proportionately more difficult as overgrowth increases. The three-rayed species $M$. contortus and $M$. tribrachiatus differ primarily in the depth of the bifurcated tips. Overgrowths tend to round the tips of $M$. contortus (Plate 8, Fig. 1), making specimens difficult to distinguish from $M$. tribrachiatus. Both taxa are Eocene marker species. This probably explains some minor discrepancies between the range chart for Hole 245 in the present study (Table 1) and the one by Bukry (1974, fig. 4).

Another example is the group Nannotetrina fulgens, $N$. cristata, and N. pappi. All occur together at the same time-stratigraphic interval and the major distinction between them appears to be size $(N$. fulgens is much larger than either $N$. cristata or $N$. pappi) and the number and orientation of lateral spines or rays. $N$. fulgens, a fourrayed form with a "web" stretching between the rays, may begin to take the squarish shape of $N$. cristata 


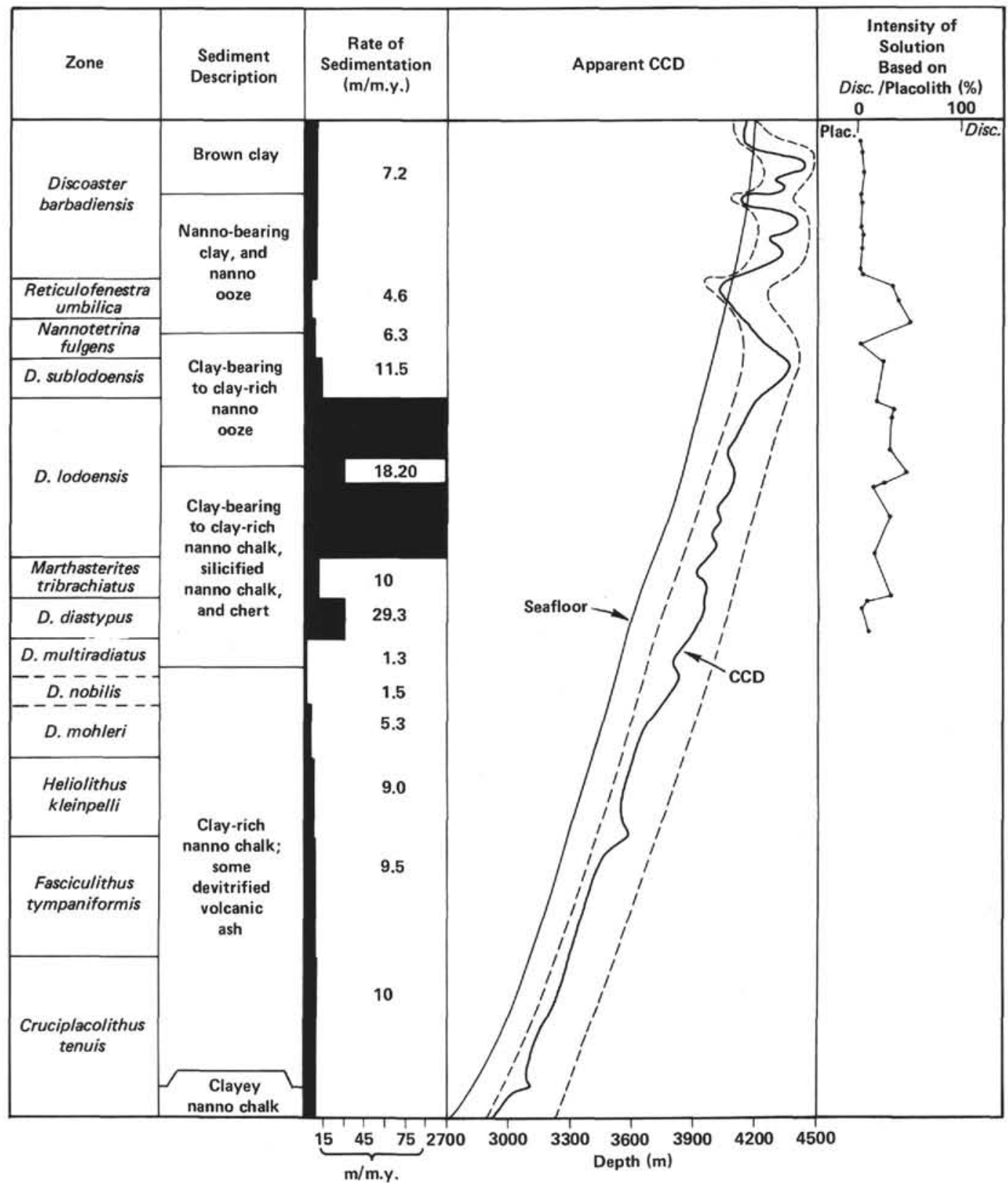

Figure 8. Lithologic descriptions for Site 245; sedimentation rate/zone (as determined from zonal boundaries in this study along with the sediment cored); paleodepth and CCD through time at Site 245 according to Berger's (1972) back-tracking method; and the Discoaster/placolith ratio (an indicator of solution intensity).

(Plate 5, Figs. 5-6). Perch-Nielsen (1970, fig. 22) illustrated what could be a close taxonomic link between a specimen of $N$. pappi and $N$. cristata, but this could well be a diagenetic link, with $N$. cristata transforming into $N$. pappi via secondary calcite overgrowth (Pl. 5, Figs. 6-8). Only $N$. fulgens and $N$. cristata are recognized as species in this study whereas those forms that resemble $N$. pappi are grouped under $N$. cristata.

\section{CONCLUSIONS}

\section{Biostratigraphy}

A mid-latitude biostratigraphic zonation of the $\mathrm{Pa}$ leocene-Eocene calcareous nannofossils from the south- west Indian and southeast Atlantic oceans has been compiled. A combination of zones adapted from the zonations of Martini (1970) and Bukry (1973a) was developed in order to avoid creating new zones or establishing new marker species. Subzones were not used because they depend on local conditions and preservation.

\section{Paleoecology}

Several warming and cooling trends are suggested in the Paleocene and Eocene. For instance, in the middle Paleocene, Haq and Lohmann (1976) propose a cooling trend in the North Atlantic between 59 and $57 \mathrm{Ma}$, based on the migration of a high-latitude Prinsius bisulcus assemblage into low latitudes. A similar cooling trend at 
Site 245 seems to be suggested between 59 and $58 \mathrm{Ma}$ (Fasciculithus tympaniformis Zone) by a high number of the species $P$. bisculcus (Fig. 7).

In the Paleocene and Eocene the surface water regime at Sites 360 and 361 was generally cooler than at Site 245 , as indicated by cooler-water assemblages off South- west Africa. For instance, the cool-water species such as Chiasmolithus oamaruensis are found only at Site 360 . This would require circulation patterns (Fig. 9) similar to those found today. Then as now, surface water temperatures off Southwest Africa would be directly affected by Antarctic cooling trends, whereas the western
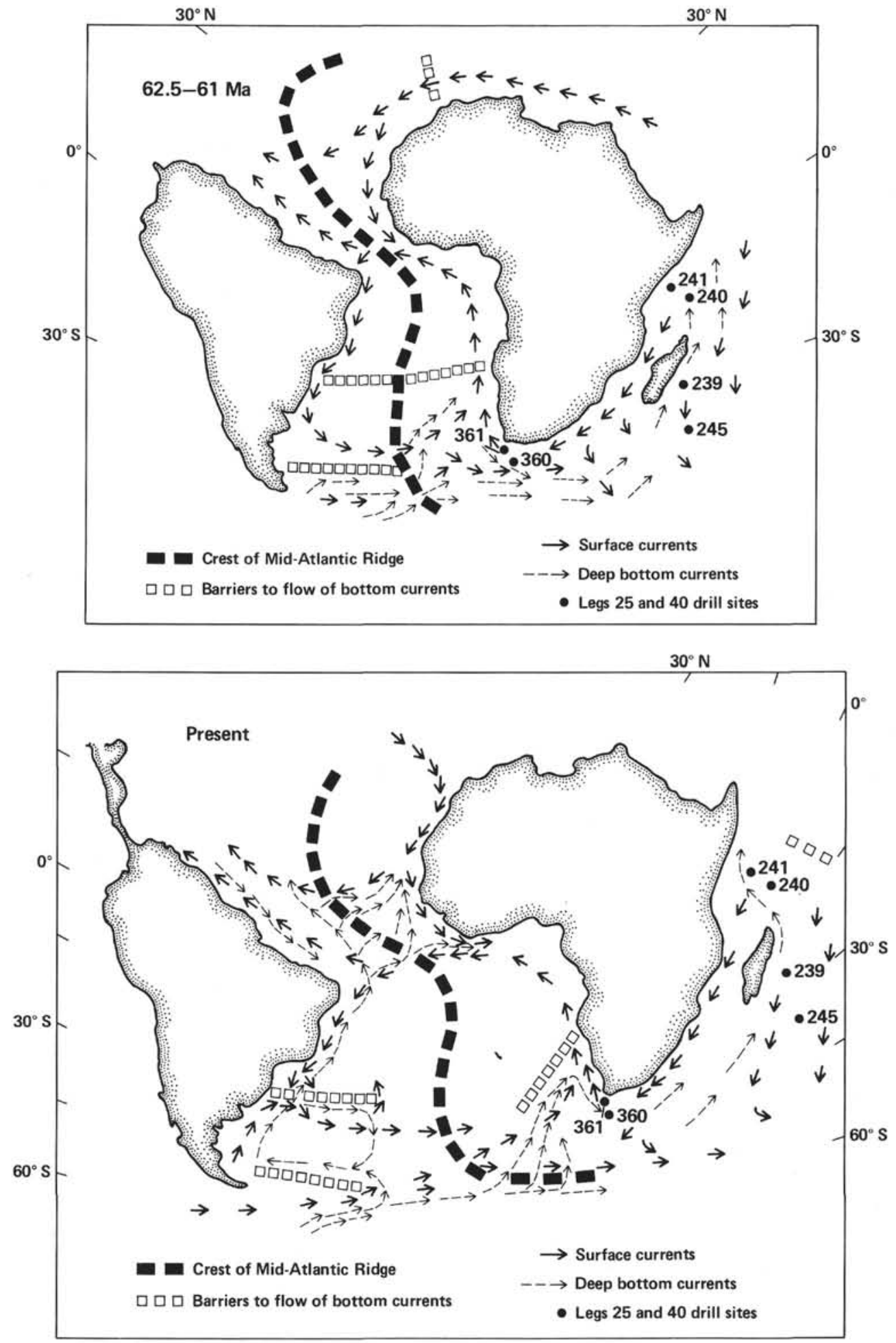

Figure 9. Map showing the relative positions of Africa and South America, presumed surface and bottom current directions, and DSDP drilling sites examined in this investigation, in the early Paleocene (62.5-61 Ma) and at the present time. Modified from Berggren and Hollister (1974, fig. 16). 
Indian Ocean would be influenced principally by the warm counterclockwise gyre that swings south along western Africa after passing through tropical climates to the north. Cool surface water flowing eastward from Antarctica, south of Site 245, should have a cooling effect on the Indian Ocean surface waters with time.

Although the Discoaster/Chiasmolithus ratio has been used previously as a means of determining average surface water temperature (Bukry, 1973b), it was found to be unreliable in the present study because of dissolution (Fig. 7), for successful use requires well-preserved samples. Samples exposed to dissolution will become preferentially enriched in discoasters through selective removal of less resistant chiasmoliths.

\section{Dissolution/Preservation}

Paleocene coccolith assemblages were generally heavily etched with little overgrowth. Presumably, etching was initially less evident for those individuals carried to the bottom in fecal pellets. However, the rate of deposition during this period was low $(\sim 10.0 \mathrm{~m} / \mathrm{m} . \mathrm{y}$.), thus extending the length of time a coccolith is exposed to dissolution at the sediment/water interface and decreasing the amount of in situ overgrowths. The proximity of the CCD to the seafloor at this time was also a factor affecting preservation.

Increasing rates of sedimentation in the early and middle Eocene removed coccoliths from the corrosive sediment/water interface more quickly than in the $\mathrm{Pa}$ leocene. Trapped interstitial pore fluids, initially undersaturated in calcium carbonate, dissolved less resistant nannofossil species and redeposited the calcite on individuals more susceptible to overgrowth (see Wise, 1976). This sequence is especially prominent in the Discoaster lodoensis Zone which had the highest sedimentation rate/zone (182 m/m.y.) encountered and the heaviest accumulation of overgrowths. The high rate of carbonate productivity also lowered the CCD but may have raised the lysocline, thus preconditioning the sediment for subsequent in situ diagenesis (Wise, 1976).

A fracture surface from Sample 245-3-5, 91-92 cm was examined with the SEM (Plate 9, Figs. 1-5) in an effort to observe effects of the dissolution-diffusion-reprecipitation process which occurs after burial (Schlanger and Douglas, 1974; Wise, 1976). The disaggregation of weakly cemented individuals is one of the first events to occur with burial, as an equilibrium is established between the biogenic calcite and the pore fluids. The pore fluids can then dissolve the small disaggregated crystals and redeposit the calcite on nannofossils on which exposed elemental surfaces are oriented perpendicular to their optic C-axis (Coccolithus, Discoaster, etc.). Plate 9 , Figure 3 shows a $D$. barbadiensis of which the radial elements are now overgrown with blocky calcite and several pieces of disaggregated calcite crystal that would eventually be incorporated into the discoaster structure to produce the type of specimen seen in Plate 10, Figure 3. Other examples of this type are seen in Plate 10, Figures 1,2 , and 4 .

Overgrowths continue within the sediment pile until nearly all weakly resistant individuals are reduced to mi- cron-sized particles, and large blocks of calcite begin to grow within the sediment. This is best illustrated in Plate 5 , Figure 4 , where a calcareous nannofossil has become so overgrown that only two large blocks of calcite, apparently joined at one end, are left. These rectangular blocks are growing at the expense of disaggregated and whole calcareous nannofossils, a situation earlier described by Wise and Hsü (1971).

As mentioned previously, the Discoaster/placolith ratio was examined to determine the intensity of dissolution a sample has undergone (Ramsay, 1972). In a typical sequence, well-preserved samples should have a low ratio and poorly preserved samples which have undergone intense dissolution should have a high ratio. However, in many cases, well-preserved samples had higher percentages of discoasters than adjacent samples with poor preservation (Table 6), perhaps because of a higher incidence of in situ overgrowths in the well-preserved samples. These overgrowths are stable in the environment in which they formed. Thus the dissolution-reprecipitation process tends to preserve discoasters at the expense of placoliths. This results in a higher Discoaster/ placolith ratio which mimics that characteristic of assemblages which have suffered dissolution only (in the water column or at the sediment/water interface).

\section{SUMMARY}

A mid-latitude biostratigraphic zonation for Paleocene and Eocene nannofossils was adopted for the examination of DSDP Holes 239, 240A, 241, 245, 245A, 360 , and 361 . This area includes the western Indian and southeast Atlantic oceans. The zones used are taken from Martini (1970) and Bukry (1973a).

Sediments recovered at Site 245 provide a nearly complete stratigraphic section through the Paleocene and Eocene. With the exception of the Discoaster nobilis Zone, all zones described were represented at this site. The $D$. nobilis Zone apparently lies between the sampled intervals 245-10-1, 70-72 cm, and 245-9-3, 120-122 cm. The D. nobilis Zone was present, however, at Site 361 .

Range charts from Holes 245A and 361 indicate several upward excursions of the CCD during the middle to late Eocene. The nannofossil assemblages at Site 360 also suggest cooler surface water temperatures than those at Site 245. Cool water species (i.e., Chiasmolithus oamaruensis, Reticulofenestra bisecta, Neococcolithus dubius, Coccolithus pelagicus, etc.) are more abundant in each sample from Site 360 . As Sites 360 and 361 are currently influenced by cooler Atlantic Ocean surface waters, one can speculate that similar circulation patterns and comparable surface water temperatures existed for the southern Atlantic and western Indian Ocean in the Paleocene and Eocene.

The Discoaster/Chiasmolithus ratio was examined at Site $\mathbf{2 4 5}$ as an additional means of determining temperature fluctuations. However, the ratio was found at least in part to be related to preservation, with higher ratios occurring in poorly preserved samples (those showing either strong dissolution or heavy secondary calcite overgrowths). The large number of poor to moderately preserved samples at Site $\mathbf{2 4 5}$ limits the use of this technique 
in this study. If preservational factors are considered, this ratio may be useful when averaged over many samples in a sequence.

Dissolution features were evident in all samples examined. Paleocene assemblages were heavily etched with little overgrowth. Low rates of deposition combined with a high CCD are considered the primary causes of this dissolution.

Increasing rates of carbonate deposition in the Eocene depressed the $\mathrm{CCD}$, thus decreasing the intensity of dissolution and increasing the amount of overgrowth. The highest rate of sedimentation, $182 \mathrm{~m} / \mathrm{m} . \mathrm{y}$, coupled with heavy overgrowth occurs in the Discoaster lodoensis Zone.

In situ dissolution and overgrowth were examined by SEM. Loading pressures and corrosive pore fluids initially break down coccoliths into individual elements. These elements are subsequently dissolved and the calcite redeposited on more resistant forms as overgrowths.

The intensity of solution that a sample has undergone was examined using the Discoaster/placolith ratios. As with the Discoaster/Chiasmolithus ratios, this technique did not appear to be valid at Site 245. Many samples with better preservation had higher ratios than samples with poor preservation because of in situ diagenetic processes. Dissolution and overgrowth posed some perplexing problems with respect to biostratigraphy in this study. Marker species within the genera Marthasterites and Nannotetrina were especially difficult to recognize because of the accrued similarity, through overgrowth, to other species of the same genus.

\section{ACKNOWLEDGMENTS}

This report was condensed from a Master of Science thesis submitted by the senior author to the Department of Geology, Florida State University (MacKenzie, 1977). We thank Yang ja Chung for slide preparations, Alan Brown and Kim Riddle for photographic assistance, Mrs. Marjorie Knapp for the drafting, Mary Parker and Rob Case for manuscript preparation, and Bill Miller for SEM photography. Dennis Cassidy, Frank Wind, and A. F. Kaharoeddin assisted in innumerable ways while the study was carried out at the FSU Antarctic Marine Geology Facility. Murlene W. Clark, James A. Bergen, and Thomas H. Lang reviewed various drafts of the manuscript. Financial support has been provided by NSF grants DPP 78-07183 and 8020382.

\section{REFERENCES}

Barker, P. F., Dalziel, I. W. D., et al., 1977. Init. Repts. DSDP, 36: Washington (U.S. Govt. Printing Office).

Berger, W. H., 1972. Deep-sea carbonates: Dissolution facies and agedepth constancy. Nature, 236:392-395.

1975. Dissolution of deep-sea carbonates: An introduction. In Sliter, W. V., Bé, A. W. H., and Berger, W. H., (Eds.), Dissolution of Deep-Sea Carbonates. Cushman Found. Foram. Research, Spec. Publ., 13:7-10.

Berggren, W. A., and Hollister, C. D., 1974. Paleogeography, paleobiogeography, and the history of circulation in the Atlantic Ocean. In Hay, W. W. (Ed.) Studies in Paleo-oceanography, Soc. Econ. Paleontol. Mineral., Spec. Publ. 20:126-186.

Bolli, H. M., Ryan, W. B. F., et al., 1978. Init. Repts. DSDP, 40: Washington (U.S. Govt. Printing Office).

Bramlette, M. N., 1961. Pelagic sediments. In Sears, M. (Ed.), Oceanography. Am. Assoc. Adv. Sci. Publ., 67:345-366.

Bramlette, M. N., and Sullivan, F. R., 1961. Coccolithophorids and related nannoplankton of the early Tertiary in California. Micropaleontology, 7:129-188.
Brönnimann, P., and Stradner, H., 1960. Die Foraminiferen und Discoasteridensonen von Kuba und ihre interkontinentale Korrelation. Erdoel Erdgas Z., 76:364-369.

Bukry, D., 1971a Cenozoic calcareous nannofossils from the Pacific Ocean. Trans. San Diego Soc. Nat. Hist., 16:303-327. 1971b. Coccolith stratigraphy, Leg 6, Deep Sea Drilling Project. In Fischer, A. G., Heezen, B. C., et al., Init. Repts. $D S D P, 6$ : Washington (U.S. Govt. Printing Office), 965-1003. 1971c. Coccolith stratigraphy Leg 7, Deep Sea Drilling Project. In Winterer, E. L., Riedel, W. R., et al., Init. Repts. DSDP, 7, Pt. 2: Washington (U.S. Govt. Printing Office), 1513-1528. , 1973a. Low-latitude coccolith biostratigraphic zonation. In Edgar, N. T., Saunders, J. B., et al., Init. Repts. DSDP, 15: Washington (U.S. Govt. Printing Office), 685-703. 1973b. Coccolith stratigraphy, Eastern Equatorial Pacific, Leg 16, Deep Sea Drilling Project. In van Andel, Tj. H., Heath, G. R., et al., Init. Repts. DSDP, 16: Washington (U.S. Govt. Printing Office), 653-711.

1974. Phytoplankton stratigraphy offshore East Africa, Deep Sea Drilling Project, Leg 25. In Simpson, E. S. W., Schlich, R. et al., Init. Repts. DSDP, 25: Washington (U.S. Govt. Printing Office), 635-646.

1978. Cenozoic silicoflagellate and coccolith stratigraphy, southeastern Atlantic Ocean, Deep Sea Drilling Project Leg 40. In Bolli, H. M., Ryan, W. B. F., et al., Init. Repts. DSDP, 40: Washington (U.S. Govt. Printing Office), 635-649.

Constans, R. E., 1975. A study of fluctuations in the carbonate compensation depth in the southern ocean south of Australia using calcareous nannofossils [M.S. thesis]. Florida State University, Tallahassee.

Edwards, A. R., 1973. Calcareous nannofossils from the Southwest Pacific Deep Sea Drilling Project, Leg 21. In Burns, R. E., Andrews, J. E., et al., Init. Repts. DSDP, 21: Washington (U.S. Govt. Printing Office), 641-691.

Haq, B. U., and Lohmann, G. P., 1976. Early Cenozoic calcareous nannoplankton biogeography of the Atlantic Ocean. Mar. Micropaleontol., 1:119-194.

Hay, W. W., 1964. Utilisation stratigraphique des Discoasterides pour la zonation du Palèogene et de l'Eocène inférieur. Mem. Bur. Rech. Geol. Min., 28:885-889.

1970. Calcareous nannofossils from cores recovered on Leg 4. In Bader, R. G., Gerard, R. D., et al., Init. Repts. DSDP, 4: Washington (U.S. Govt. Printing Office), 455-501.

Heck, S. E. van, 1979a. Internat. Nannoplankton Assoc. Newsl., 1(no. 1).

1979b. Internat. Nannoplankton Assoc. Newsl., 1(no. 2). 1980. Internat. Nannoplankton Assoc. Newsl., 2(no. 1).

Honjo, S., 1976. Coccoliths: production, transportation, and sedimentation. Mar. Micropaleontol., 1:65-79.

Lisitzin, A. P., 1972. Sedimentation in the world ocean. In Rodolfo, K. S. (Ed.), Soc. Econ. Paleontol. Mineral., Spec. Publ., 17:1-218.

Loeblich, A. R., Jr., and Tappan, H., 1966. Annotated index and bibliography of the calcareous nannoplankton. Phycologia, 5:81-216. 1968. Annotated index and bibliography of the calcareous nannoplankton III. J. Paleontol., 42:584-598. 1969. Annotated index and bibliography of the calcareous nannoplankton III. J. Paleontol., 43:568-588. 1970a. Annotated index and bibliography of the calcareous nannoplankton IV. J. Paleontol., 44:558-574. $1970 \mathrm{~b}$. Annotated index and bibliography of the calcareous nannoplankton VI. Phycologia, 9:157-174.

1971. Annotated index and bibliography of the calcareous nannoplankton VII. Phycologia, 10:315-339.

1973. Annotated index and bibliography of the calcareous nannoplankton VII. J. Paleontol., 47:715-759.

McIntyre, A., Bé, A. W. H., and Preikstas, R., 1967. Coccoliths and the Pliocene-Pleistocene boundary. In Sears, M. (Ed.), Progress in Oceanography (Vol. 4): London (Pergamon Press), 3-25.

Mackenzie, D. T., 1977. A comparative analysis of Lower Tertiary calcareous nannofossils from Southern Oceans [M.S. thesis]. Florida State University, Tallahassee.

Martini, E., 1970. Standard Paleogene calcareous nannoplankton zonation. Nature, 226:560-561. 
1971. Standard Tertiary and Quaternary calcareous nannoplankton zonation. In Farinacci, A. (Ed.), Proc. II Planktonic Conf.: Rome (Edizioni Tecnoscienza), pp. 739-785.

Mohler, H. P., and Hay, W. W., 1967. Zonation of the Paleocenelower Eocene interval. In Hay, W. W., Mohler, H. P., Roth, P. H., Schmidt, R. R., and Boudreaux, J. E. (Eds.), Trans. Gulf Coast Assoc Geol. Soc., 17:432-439.

Muller, C., 1974. Calcareous nannoplankton, Leg 25 (Western Indian Ocean). In Simpson, E. S. W., Schlich, R., et al., Init. Repts. $D S D P, 25$ : Washington (U.S. Govt. Printing Office), 579-634.

Murray, J., and Renard, A. F., 1891. Report on deep-sea deposits based on the specimens collected during the voyage of H.M.S. Challenger in the years 1872 to 1876. Report on the Scientific Results of the Voyage of H.M.S. Challenger During the Years 1872-76, Pt. 3, Deep-sea deposits.

Perch-Nielsen, K., 1970. Dursicht tertiärer Coccolithen. Proc. II Planktonic Conf. (Vol. 2): Rome (Edizioni Tecnoscienza), 939-979.

1972. Remarks on Late Cretaceous to Pleistocene coccoliths from the North Atlantic. In Laughton, A. S., Berggren, W. A., et al., Init. Repts. DSDP, 12: Washington (U.S. Govt. Printing Office), 1003-1069.

Peterson, M. N. A., 1966. Calcite: Rates of dissolution in a vertical profile in the Central Pacific. Science, 154:1542-1544.

Proto Decima, F.,. Medizza, F., and Todesco, L., 1978. Southeastern Atlantic Leg 40 calcareous nannofossils. In Bolli, H. M., Ryan, W. B. F., et al., Init. Repts. DSDP, 40: Washington (U.S. Govt. Printing Office), 571-634.

Ramsay, A. T. S., 1972. Aspects of the distribution of fossil species of calcareous nannoplankton in North Atlantic and Caribbean sediments. Nature, 236:67-70.

1977. Sedimentological clues to palaeo-oceanography. In Ramsay, A. T. S. (Ed.), Oceanic Micropalaeontology (Vol. 2): New York (Academic Press), 1371-1453.

Ramsay, A. T. S., Schneidermann, N., and Finch, J. W., 1973. Fluctuations in the past rates of carbonate solution at Site 149: A comparison with other ocean basins and an interpretation of their significance. In Edgar, N. T., Saunders, J. B., et al., Init. Repts. DSDP, 15: Washington (U.S. Govt. Printing Office), 805-811.

Roth, P. H., 1973. Calcareous nannofossils Leg 17, Deep Sea Drilling Project. In Winterer, E. L., Ewing, J. I., et al., Init. Repts. DSDP, 17: Washington (U.S. Govt. Printing Office), 675-796.

Roth, P. H., Mullin, M. N., and Berger, W. H., 1975. Coccolith sedimentation by fecal pellets: Laboratory experiments and field observations. Geol. Soc. Am. Bull., 86:1079-1084.

Roth, P. H., and Thierstein, H., 1972. Calcareous nannoplankton: Leg 14 of the Deep Sea Drilling Project. In Hayes, D. E., Pimm, A. C., et al., Init. Repts. DSDP, 14: Washington (U.S. Govt. Printing Office), 421-485.

Roth, P. H., Wise, S. W., and Thierstein, H., 1975. Early chalk diagenesis and lithification: Sedimentological applications of paleontological approaches. IX $X^{m e}$ Cong. Int. Sedimentol., Nice, 1975, Thème 7 (Progrès dans la connaissance de la diagénèse (sauf grands fonds), pp. 187-192.

Schlanger, S. O., and Douglas, R. G., 1974. The pelagic-ooze-chalklimestone transition and its implication for marine stratigraphy. In Hsü, K. J., and Jenkyns, H. (Eds.), Pelagic Sediments on Land and Under the Sea. Spec. Publ. Int. Assoc. Sedimentol., 1:117-148.

Schlich, R., 1974. Sea floor spreading history and deep-sea drilling results in the Madagascar and Mascarene Basins, Western Indian Ocean. In Simpson, E. S. W., Schlich, R., et al., Init. Repts. $D S D P, 25$ : Washington (U.S. Govt. Printing Office), 663-678.

Schneidermann, N., 1973. Deposition of coccoliths in the compensation zone of the Atlantic Ocean. In Smith, L. A., and Hardenbol, J. (Eds.), Proceedings of a Symposium on Calcareous Nannofossils: Houston, Texas (Soc. Econ. Paleontol. Mineral.), pp. 140-151.

1977. Selective dissolution of recent coccoliths in the Atlantic Ocean. In Ramsay, A. T. S. (Ed.), Oceanic Micropalaeontology (Vol. 2): New York (Academic Press), 1009-1046.

Siesser, W. G., 1975. Calcareous nannofossils from the South African continental margin. Mar. Geol. Prog., 5:1-135.

Simpson, E. S. W., Schlich, R., et al., 1974. Init. Repts. DSDP, 25: Washington (U.S. Govt. Printing Office).
Thierstein, H. R., 1974. Calcareous nannoplankton-Leg 26, Deep Sea Drilling Project. In Davies, T. A., Luyendyk, B. P., et al., Init. Repts. DSDP, 26: Washington (U.S. Govt. Printing Office), 619-667.

Wise, S. W., 1972. Calcite overgrowths on calcareous nannofossilsa taxonomic irritant and a key to the formation of chalk. Geol. Soc. Am. Prog. Abstr., 4:115-116. (Abstract)

1973. Calcareous nannofossils from cores recovered by Leg 18, Deep Sea Drilling Project: Biostratigraphy and observations of diagenesis. In Kulm, L. D., von Huene, R., et al., Init. Repts. DSDP, 18: Washington, (U.S. Govt. Printing Office), 569-616. 1976. Chalk formation: Early diagenesis. In Andersen, N. R., and Malahoff, A. (Eds.), The Fate of Fossil Fuel $\mathrm{CO}_{2}$ in the Oceans: New York (Plenum), pp. 717-739.

Wise, S. W., and Hsü, K. J., 1971. Genesis and lithification of a deep sea chalk. Eclog. Geol. Helv., 64(2):273-278.

Wise, S. W., and Kelts, K. R., 1972. Inferred diagenetic history of a weakly silicified deep sea chalk. Trans. Gulf Coast Assoc. Geol. Socs., 22:177-203.

Wise, S. W., and Wind, F. H., 1977. Mesozoic and Cenozoic calcareous nannofossils recovered by DSDP Leg 36 drilled on the Falkland Plateau, Atlantic section of the Southern Ocean. In Barker, B. F., Dalziel, I. W. D., et al., Init. Repts. DSDP, 36: Washington (U.S. Govt. Printing Office), 269-492.

\section{APPENDIX A}

Paleocene and Eocene Calcareous Nannofossil Species List, Leg 25, Holes 239, 240, 241, 245, and 245A

Blackites sp.

Braarudosphaera discula Bramlette and Riedel, 1954

Chiastozygus amphipons (Bramlette and Martini) Gartner, 1968.

Chiasmolithus bidens (Bramlette and Sullivan) Hay and Mohler, 1967

C. californicus (Sullivan) Hay and Mohler, 1967

C. consuetus (Bramlette and Sullivan) Hay and Mohler, 1967

C. danicus (Brotzen) Hay and Mohler, 1967

C. gigas (Bramlette and Sullivan) Radomski, 1968

C. grandis (Bramlette and Riedel) Bukry and Kennedy, 1969

Chiphragmalithus acanthodes Bramlette and Sullivan, 1961

Coccolithus eopelagicus (Bramlette and Riedel) Bramlette and Sullivan, 1961

C. formosus (Kamptner) Wise, 1973

C. pelagicus (Wallich) Schiller, 1930

C. sarsiae Black, 1962

Cruciplacolithus staurion (Bramlette and Sullivan) Gartner, 1971

C. tenuis (Stradner) Hay and Mohler, 1967

Discoaster barbadiensis Tan, 1927

D. cruciformis Martini, 1958

D. diastypus Bramlette and Sullivan, 1961

D. gemmifer Stradner, 1961

D. lodoensis Bramlette and Riedel, 1954

D. mohleri Bukry and Percival, 1971

D. multiradiatus Bramlette and Riedel, 1954

D. nobilis Martini, 1961

D. saipanensis Bramlette and Riedel, 1954

D. sublodoensis Bramlette and Sullivan, 1961

D. tani nodifer Bramlette and Riedel, 1954

D. wemmelensis Achutan and Stradner, 1969

Discoasteroides kuepperi (Stradner) Bramlette and Sullivan, 1961

Ellipsolithus distichus (Bramlette and Sullivan) Sullivan, 1964

E. macellus (Bramlette and Sullivan) Sullivan, 1964

Eodiscoaster danicus Martini, 1961

Ericsonia subpertusa Hay and Mohler, 1967

Fasciculithus involutus Bramlette and Sullivan, 1961

F. magnus Bukry and Percival, 1971

F. tympaniformis Hay and Mohler, 1967

Heliolithus cantabriae Perch-Nielsen, 1971

H. kleinpelli Sullivan, 1964

Isthmolithus recurvus Deflandre, 1954

Markalius inversus (Deflandre) Bramlette and Martini, 1964

Marthasterites contortus (Stradner) Deflandre, 1959

M. tribrachiatus (Bramlette and Riedel) Deflandre, 1959

Nannotetrina cristata (Martini) Perch-Nielsen, 1971

N. fulgens (Stradner) Stradner, 1969 
Neochiastozygus concinnus (Martini) Perch-Nielsen, 1971

Neococcolithes protenus (Bramlette and Sullivan) Hay and Mohler, 1967

Pontosphaera multipora (Kamptner) Roth, 1970

$P$. pectinata (Bramlette and Sullivan) Proto Decima et al., 1975

P. plana (Bramlette and Sullivan) Haq, 1971

Prinsius bisulcus (Stradner) Hay and Mohler, 1967

Reticulofenestra bisecta (Hay, Mohler, and Wade) Roth, 1970

$R$. coenura (Reinhardt) Roth, 1970

$R$. hillae Bukry and Percival, 1971

R. samodurovi (Hay, Mohler, and Wade) Bukry and Percival, 1971

R. umbilica (Levin) Martini and Ritzkowski, 1968

Sphenolithus anarrhopus Bukry and Bramlette, 1969

S. moriformis (Brönnimann and Stradner) Bramlette and Wilcoxon, 1967

S. pseudoradians Bramlette and Wilcoxon, 1967

$S$. radians Deflandre, 1961

Thoracosphaera $\mathrm{sp}$.

Toweius craticulus Hay and Mohler, 1967

T. eminens (Bramlette and Sullivan) Perch-Nielsen, 1971

T. tovae Perch-Nielsen, 1971

Zygodiscus sigmoides Bramlette and Sullivan, 1961

Zygrhablithus bijugatus (Deflandre) Deflandre, 1959

\section{APPENDIX B}

Paleocene-Eocene Calcareous Nannofossil Species List, Leg 40, Holes 360 and 361

\section{Blackites sp.}

Chiasmolithus bidens (Bramlette and Sullivan) Hay and Mohler, 1967

C. expansus (Bramlette and Sullivan) Bukry and Bramlette, 1969

Chiasmolithus gigas (Bramlette and Sullivan) Radomski, 1968

C. grandis (Bramlette and Riedel) Bukry and Kennedy, 1969

C. oamaruensis (Deflandre) Hay, Mohler, and Wade, 1966

C. solitus

Chiphragmalithus acanthodes Bramlette and Sullivan, 1961

Coccolithus eopelagicus (Bramlette and Riedel) Bramlette and Sullivan, 1961

C. formosus (Kamptner) Wise, 1973

C. pelagicus (Wallich) Schiller, 1930

C. sarsiae Black, 1962

Cruciplacolithus crux (Deflandre and Fert) Roth, 1970

C. delus (Bramlette and Sullivan) Perch-Nielsen, 1971

C. mutatus Perch-Nielsen, 1971

C. staurion (Bramlette and Sullivan) Gartner, 1971
C. tenuis (Stradner) Hay and Mohler, 1967

Discoaster barbadiensis Tan, 1927

D. diastypus Bramlette and Sullivan, 1961

D. gemmifer Stradner, 1961

D. lodoensis Bramlette and Riedel, 1954

D. mirus Deflandre, 1952

D. mohleri Bukry and Percival, 1971

D. multiradiatus Bramlette and Riedel, 1954

D. nobilis Martini, 1961

D. saipanensis Bramlette and Riedel, 1954

D. sublodoensis Bramlette and Sullivan, 1961

D. tani nodifer Bramlette and Riedel, 1954

D. wemmelensis Achutan and Stradner, 1969

Discoasteroides megastypus Bramlette and Sullivan, 1961

Ericsonia muiri (Black) Roth, 1970

Fasciculithus involutus Bramlette and Sullivan, 1961

F. tympaniformis Hay and Mohler, 1967

Helicopontosphaera seminulum (Bramlette and Sullivan) Roth, 1970

Heliolithus cantabriae Perch-Nielsen, 1971

H. kleinpelli Sullivan, 1964

Heliolithus sp. 1 in Wise and Wind, 1977

Isthmolithus recurvus Deflandre, 1954

Markalius inversus (Deflandre) Bramlette and Martini, 1964

Marthasterites contortus (Stradner) Deflandre, 1959

M. tribrachiatus (Bramlette and Riedel) Deflandre, 1959

Nannotetrina cristata (Martini) Perch-Nielsen, 1971

N. fulgens (Stradner) Stradner, 1969

Phanulithus obscurus (Deflandre) Wind and Wise, 1977

Pontosphaera multipora (Kamptner) Roth 1979

P. pectinata (Bramlette and Sullivan) Proto Decima et al., 1975

P. plana (Bramlette and Sullivan) Hay, 1971

Reticulofenestra bisecta (Hay, Mohler, and Wade) Bukry and Percival, 1971

$R$. hillae Bukry and Percival, 1971

$R$. samodurovi (Hay, Mohler, and Wade) Bukry and Percival, 1971

R. umbilica (Levin) Martini and Ritzkowski, 1968

Rhabdosphaera inflata Bramlette and Sullivan, 1961

Sphenolithus moriformis (Brönnimann and Stradner) Bramlette and Wilcoxon, 1967

S. radians Deflandre, 1961

Thoracosphaera spp.

Toweius eminens (Bramlette and Sullivan) Perch-Nielsen, 1971

Transversopontis pulchra (Deflandre) Haq, 1971

Zygrhablithus bijugatus (Deflandre) Deflandre, 1959 


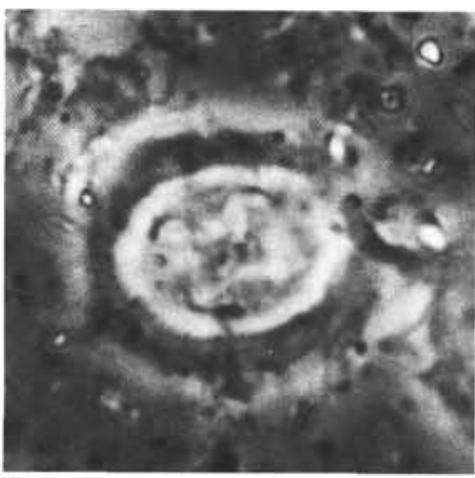

1

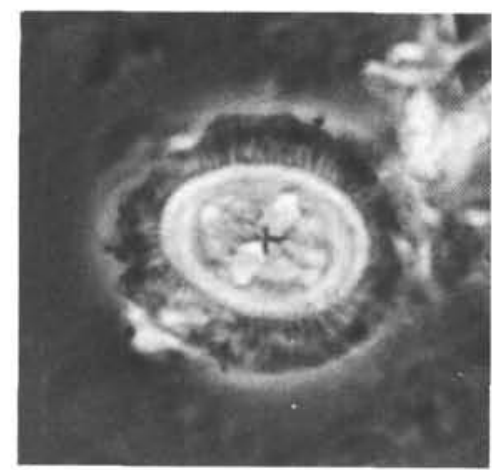

4

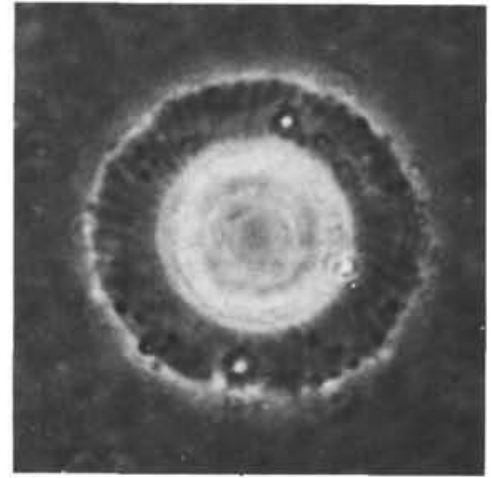

7

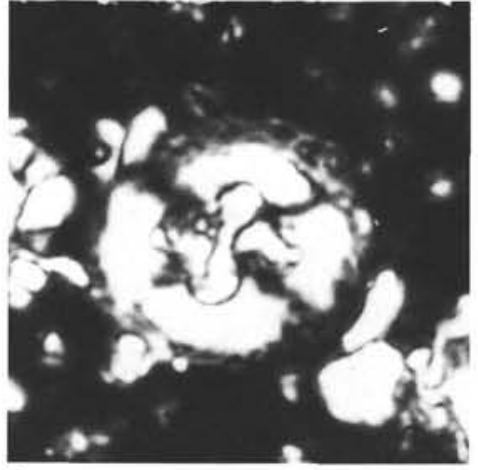

2

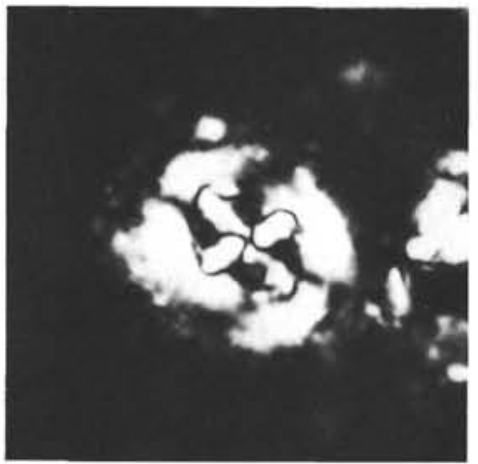

5

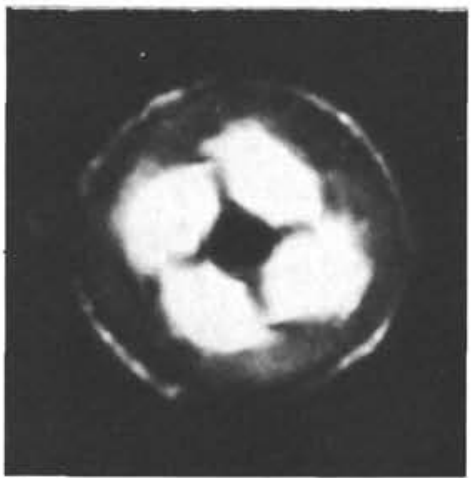

8

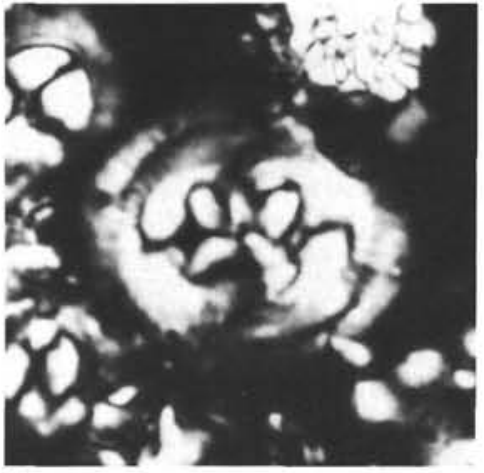

3

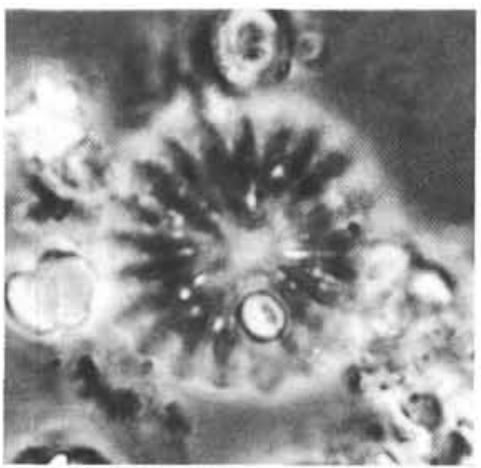

6

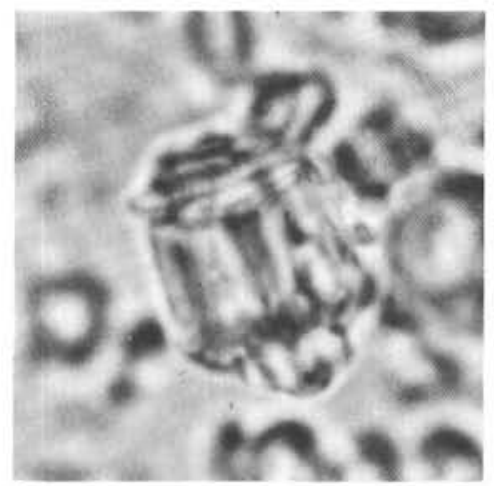

9

Plate 1. Leg 25 calcareous nannofossils. (All specimens magnified $\times 2400$.) 1-2. Chiasmolithus danicus (Brotzen) Hay and Mohler, Sample 245-15-3, 76-78 cm. 3. Chiasmolithus californicus (Sullivan) Hay and Mohler, 245-8-1, 138-140 cm. 4-5. Cruciplacolithus tenuis (Stradner) Hay and Mohler, Sample 245-12-1, 130-132 cm. 6. Discoaster multiradiatus Bramlette and Riedel, Sample 245-9-3, 52-54. 7-8. Ericsonia subpertusa Hay and Mohler, Sample 245-9-3, 52-54. 9. Fasciculithus magnus Bukry and Percival, Sample 245-9-1, 90-92 cm. 


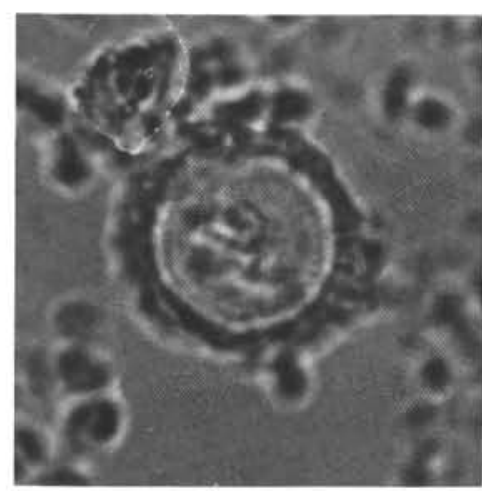

1

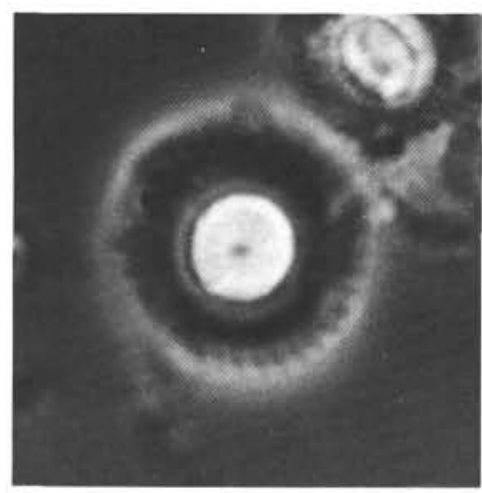

4

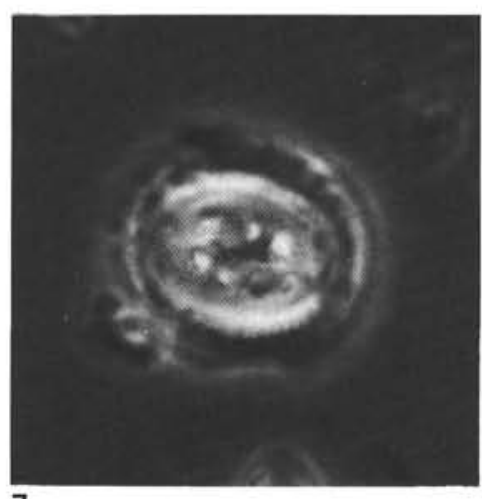

7

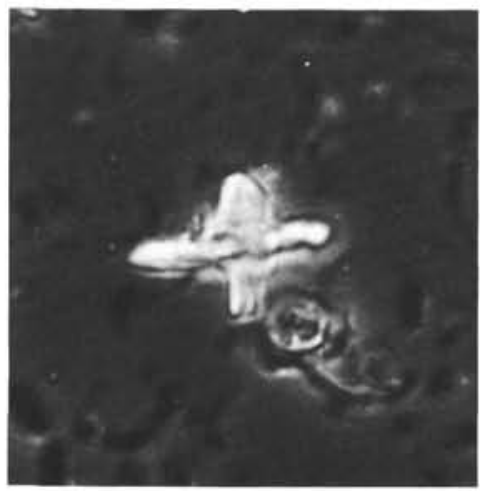

10

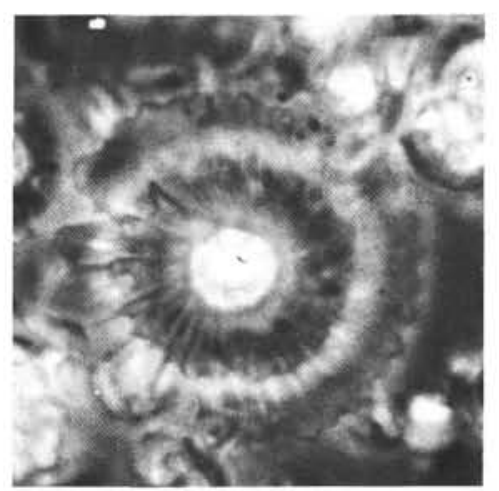

2

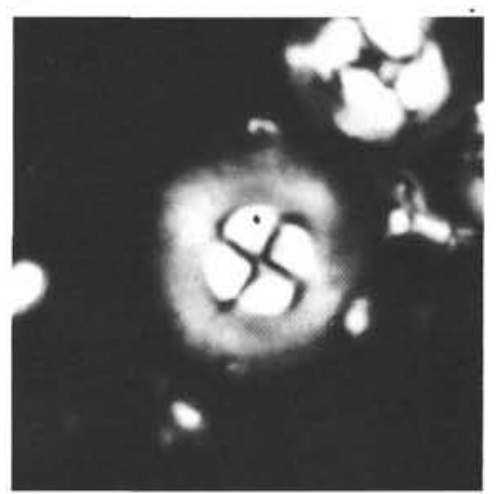

5

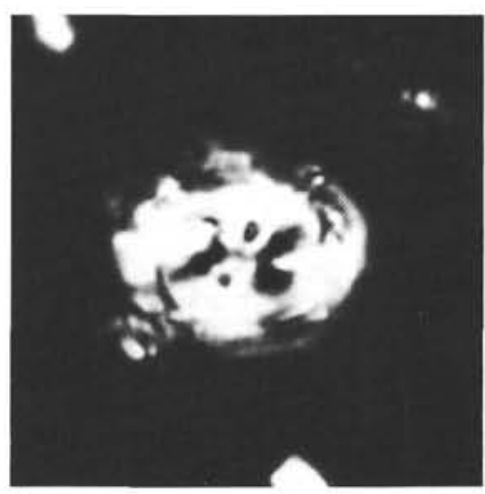

8

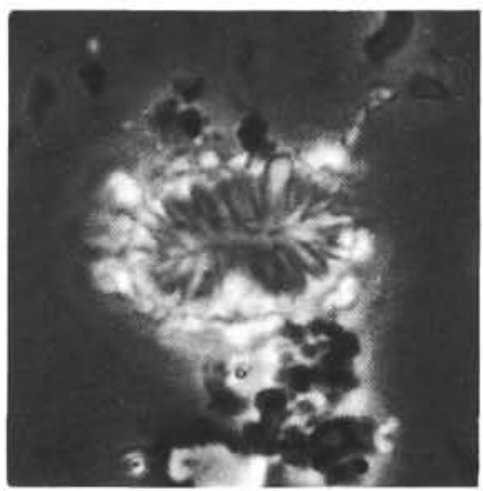

11

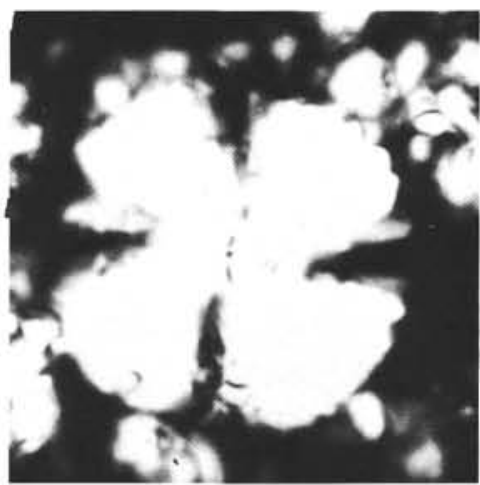

3

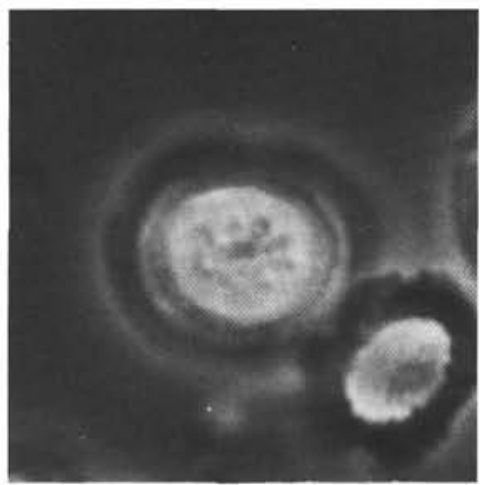

6

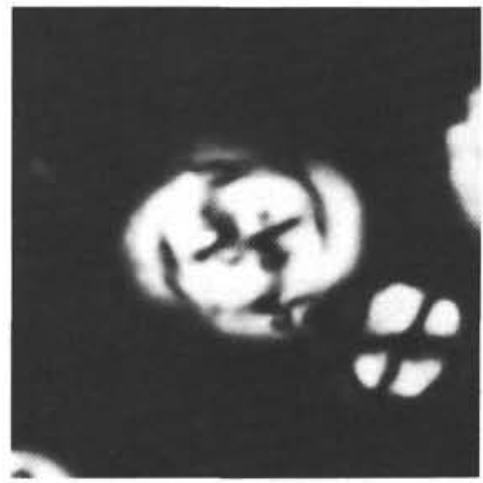

9

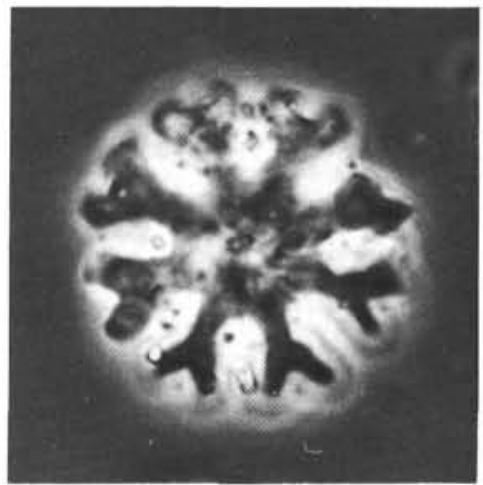

12

Plate 2. Leg 25 calcareous nannofossils. (All specimens magnified $\times 2400$ unless otherwise indicated.) 1. Heliolithus cantabriae Perch-Nielsen, Sample 245-12-1, 130-132 cm. 2-3. Heliolithus kleinpelli Sullivan, Sample 245-11-1, 102-104 cm. 4-5. Markalius inversus (Deflandre) Bramlette and Martini, Sample 245-7-1, 75-77 cm. 6-9. Toweius craticulus Hay and Mohler, Sample 245-12-4, 136-138 cm. 7-8. Toweius tovae Perch-Nielsen, Sample 245-11-2, 135-137 cm. 10. Discoaster diastypus Bramlette and Sullivan, $\times 1900,245-8-2,105-107 \mathrm{~cm}$. 11. Ellipsolithus sp. Sullivan, Sample 245-9-3, 120-122 cm. 12. Discoaster gemmifer Stradner Sample 245A-3-2, 110-112 cm. 


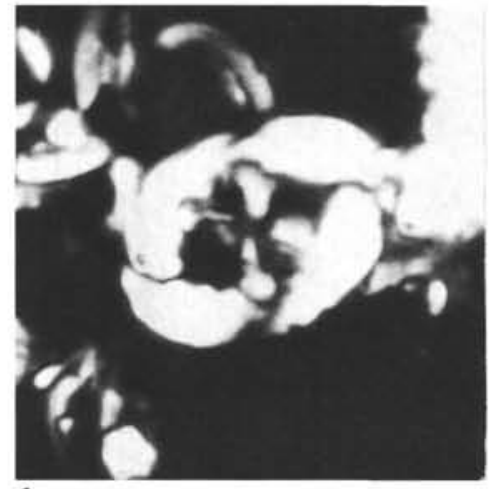

1

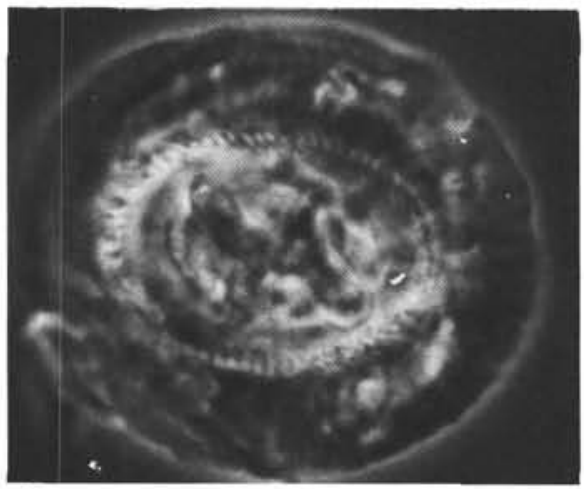

4

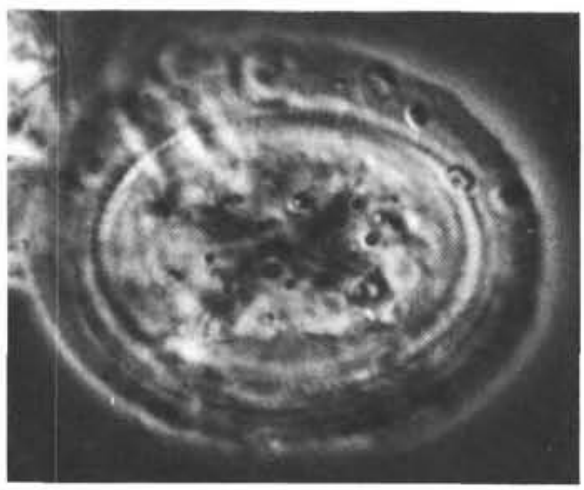

7

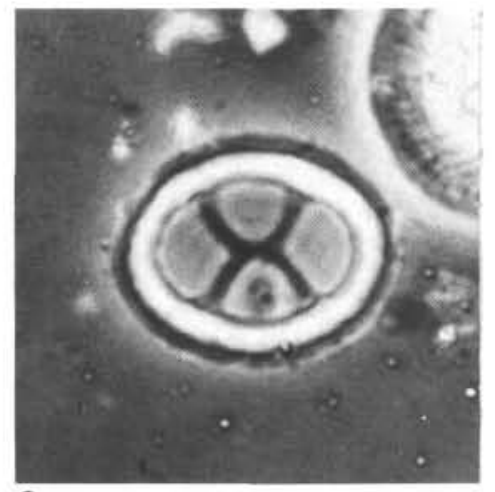

2

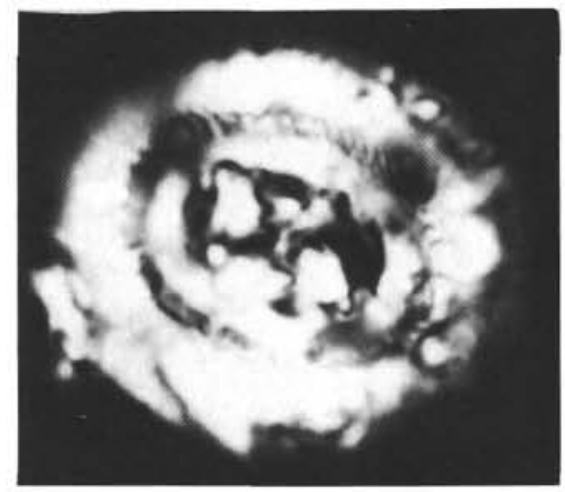

5

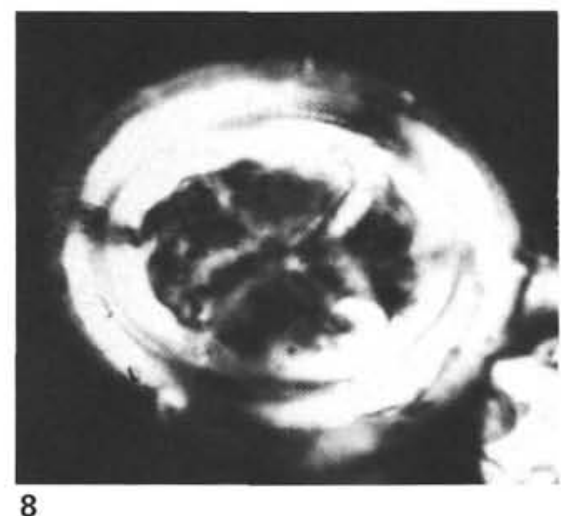

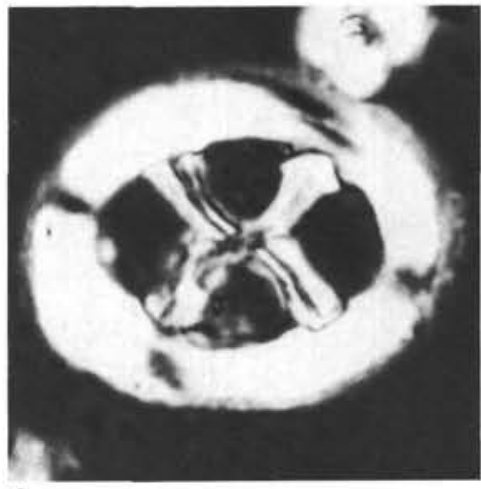

3

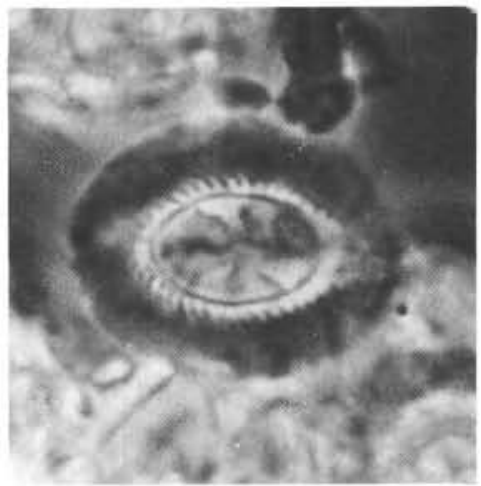

6

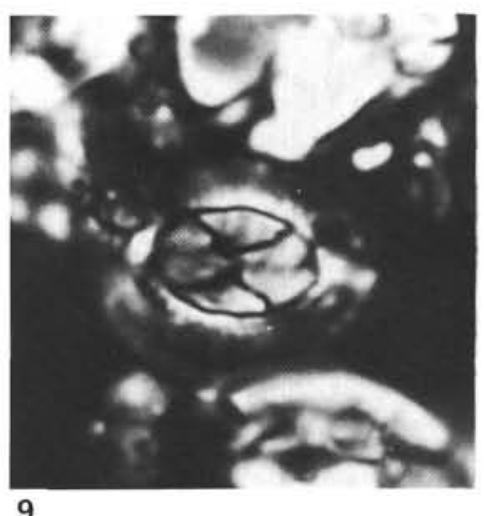

Plate 3. Leg 40 calcareous nannofossils. (All specimens magnified $\times 2400$ unless otherwise indicated.) 1. Chiasmolithus cf. C. oamaruensis (Deflandre) Hay, Mohler, and Wade, Sample 360-36-2, 44-46 cm. 2-3. Chiasmolithus expansus (Bramlette and Sullivan) Bukry and Bramlette, $\times 1900$, Sample 360-50-1, 122-124 cm. 4-5. Chiasmolithus gigas (Bramlette and Sullivan) Radomski, Sample 360-50-1, 122-124 cm. 6-9. Coccolithus cf. C. pelagicus, Sample 245-5-1, 115-117 cm. 7-8. Chiasmolithus grandis (Bramlette and Riedel) Bukry and Kennedy, Sample $360-50-1,122-124 \mathrm{~cm}$. 


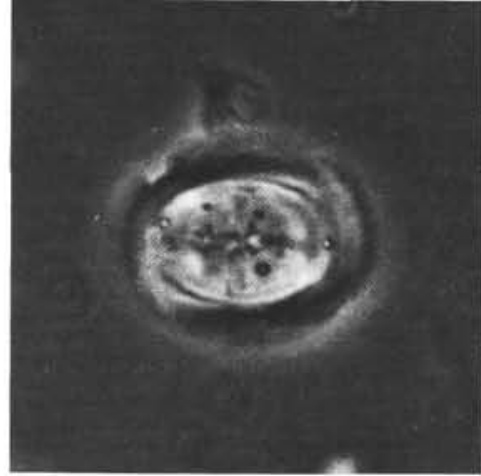

1

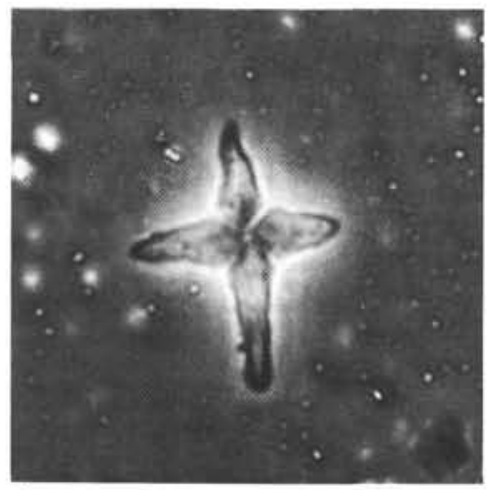

4

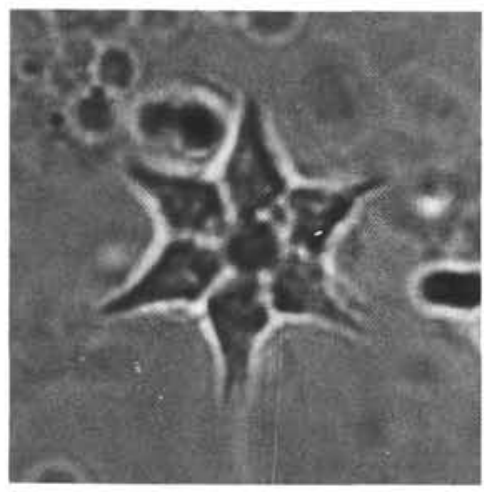

7

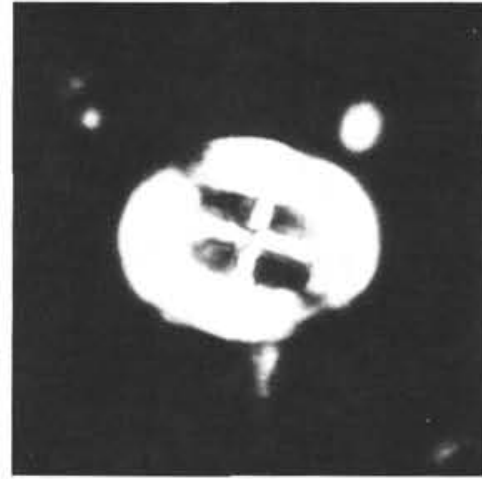

2

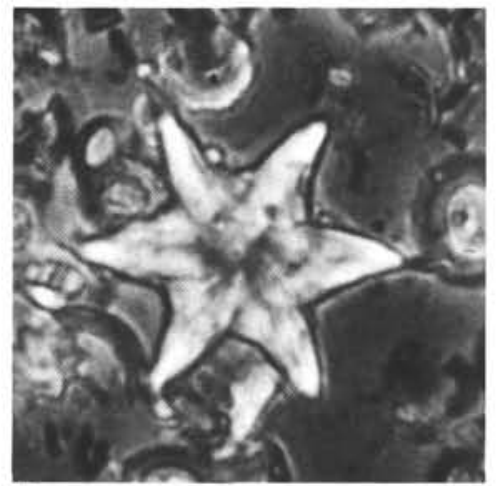

5

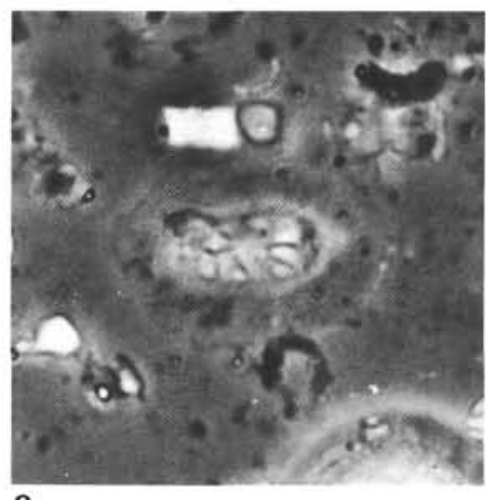

8

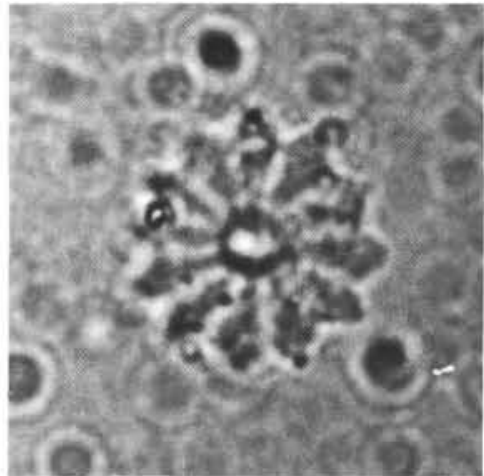

3

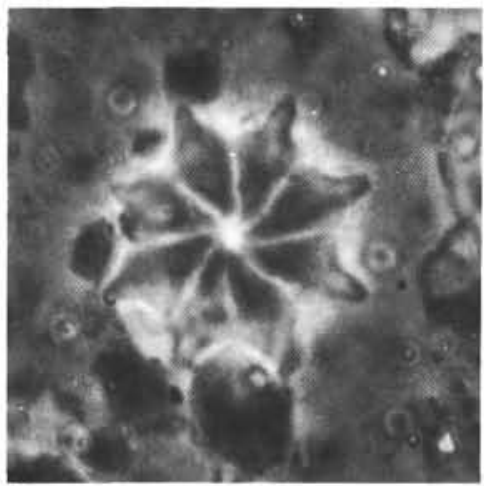

6

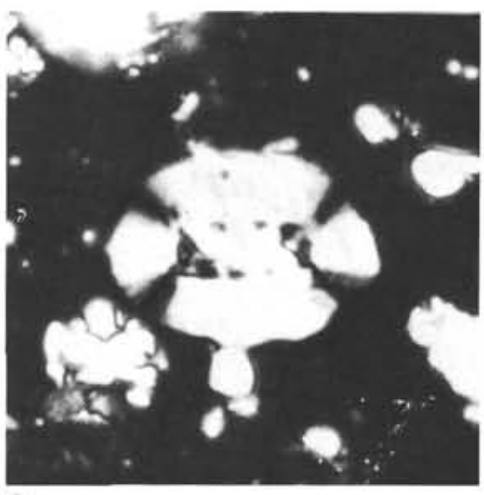

9

Plate 4. Leg 40 calcareous nannofossils. (All specimens magnified $\times 2400$ unless otherwise indicated.) 1-2. Cruciplacolithus delus (Bramlette and Sullivan) Perch-Nielsen, Sample 360-6-3, 91-93 cm. 3. Discoaster barbadiensis Tan, Sample 245-3-4, 62-64 cm. 4. Discoaster cruciformis Martini, $\times 1900$, Sample 245-7-1, 135-137 cm. 5. Discoaster lodoensis Bramlette and Riedel, $\times 1900,245-7-1,135-137 \mathrm{~cm}$. 6-7. Discoaster saipanensis Bramlette and Riedel, 245A-6-2, 138-140 cm. 8-9. Ellipsolithus distichus (Bramlette and Sullivan) Sullivan, Sample 245-8-2, $105-107 \mathrm{~cm}$. 


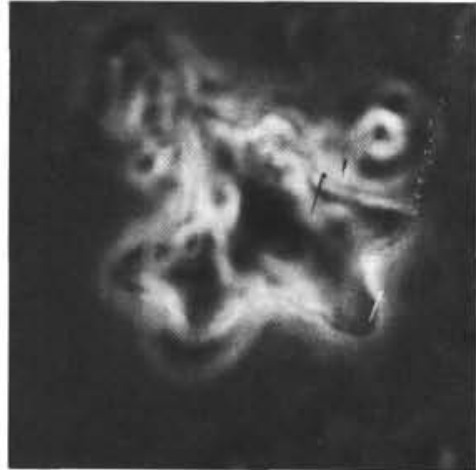

1

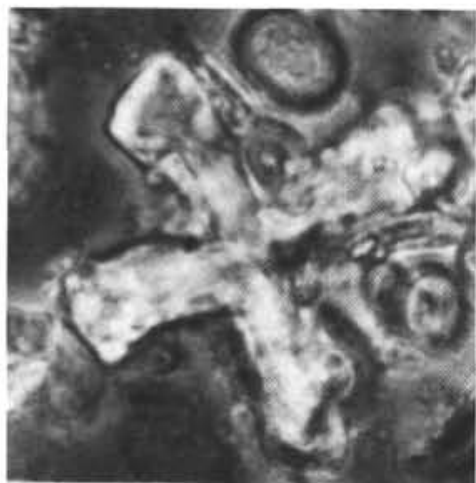

4

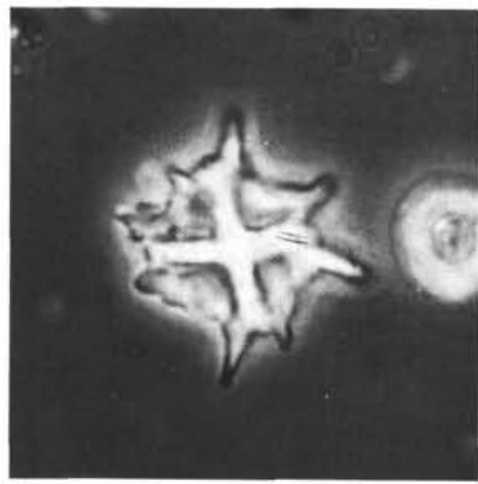

7

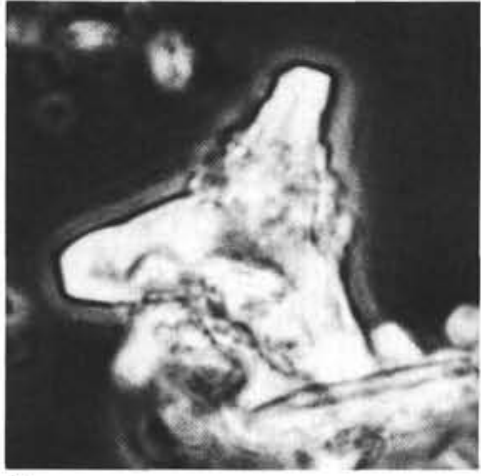
2

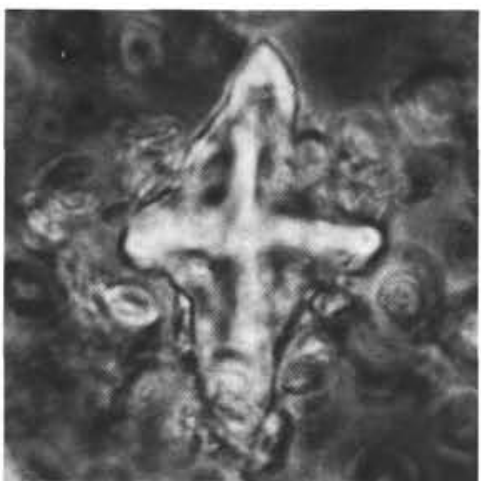

5

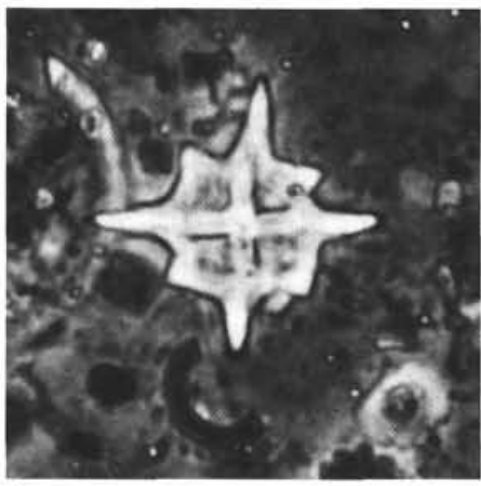

8

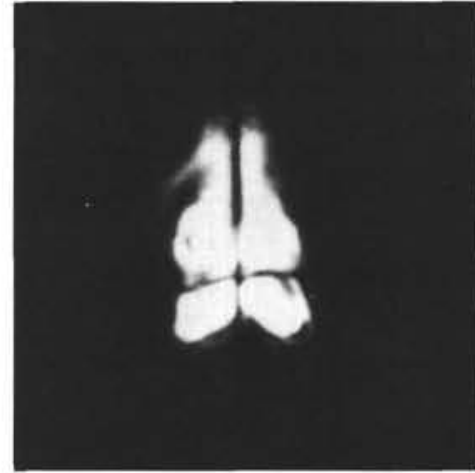

3

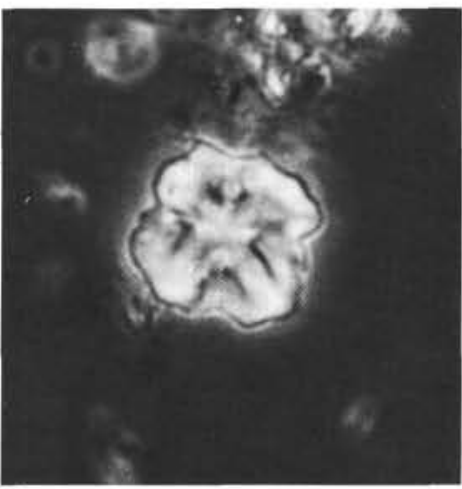

6

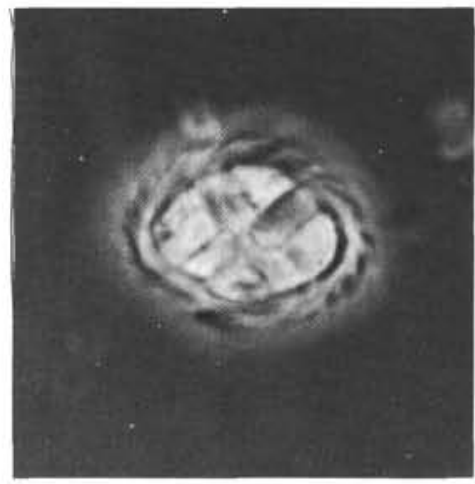

9

Plate 5. Leg 40 calcareous nannofossils. (All specimens magnified $\times 2400$ unless otherwise indicated.) 1. Marthasterites contortus (Stradner) Deflandre, Sample 361-8-1, 131-133 cm. 2. Marthasterites tribrachiatus (Bramlette and Riedel) Deflandre, Sample 245-7-2, 55-57 cm. 3. Sphenolithus radians Deflandre, Sample 245-5-4, 22-24 cm. 4-5. Nannotetrina fulgens (Stradner) Stradner, $\times 1900$, Sample 245-3-4, 62-68 $\mathrm{cm}$. 6. Nannotetrina cristata (Martini) Perch-Nielsen, Sample 245-9-1, 90-92 cm. 7-8. Nannotetrina pappi (Stradner) Perch-Nielsen, Sample $360-48-2,48-50 \mathrm{~cm}$. 9. Chiphragmalithus acanthodes Bramlette and Sullivan, Sample 245A-7-2, 115-117 cm. 

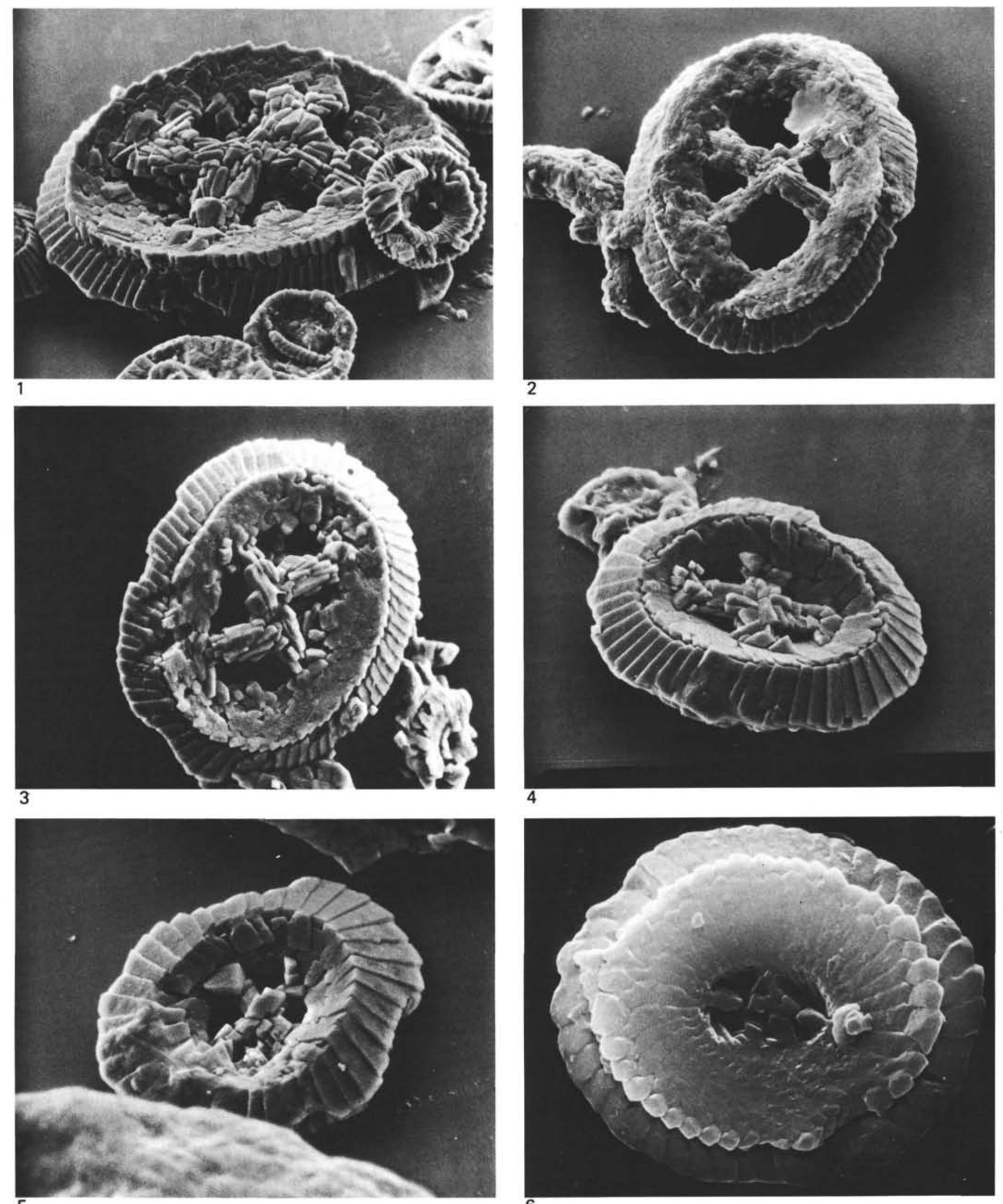
5

6

Plate 6. 1. Chiasmolithus grandis (Bramlette and Riedel) Bukry and Kennedy, distal view, $\times 4100$, Sample 245-3-5, 91-92 cm. 2. Chiasmolithus oamaruensis (Deflandre) Hay, Mohler, and Wade, distal view, $\times 4100$, Sample 360-36-2, 44-46 cm. 3. Chiasmolithus bidens (Bramlette and Sullivan) Hay and Mohler, distal view, $\times 5100$, Sample 245-8-1, 55-57 cm. 4. Cruciplacolithus tenuis (Stradner) Hay and Mohler, distal view, $\times 5400$, Sample 245-15-3, 76-78 cm. 5. Cruciplacolithus tenuis (Stradner) Hay and Mohler, distal view, $\times 7900$, Sample 245-15-3, 76-78 $\mathrm{cm}$. 6. Cruciplacolithus staurion (Bramlette and Sullivan) Gartner, proximal view, $\times 9400$, Sample $361-9-2,51-53 \mathrm{~cm}$. 



1

2
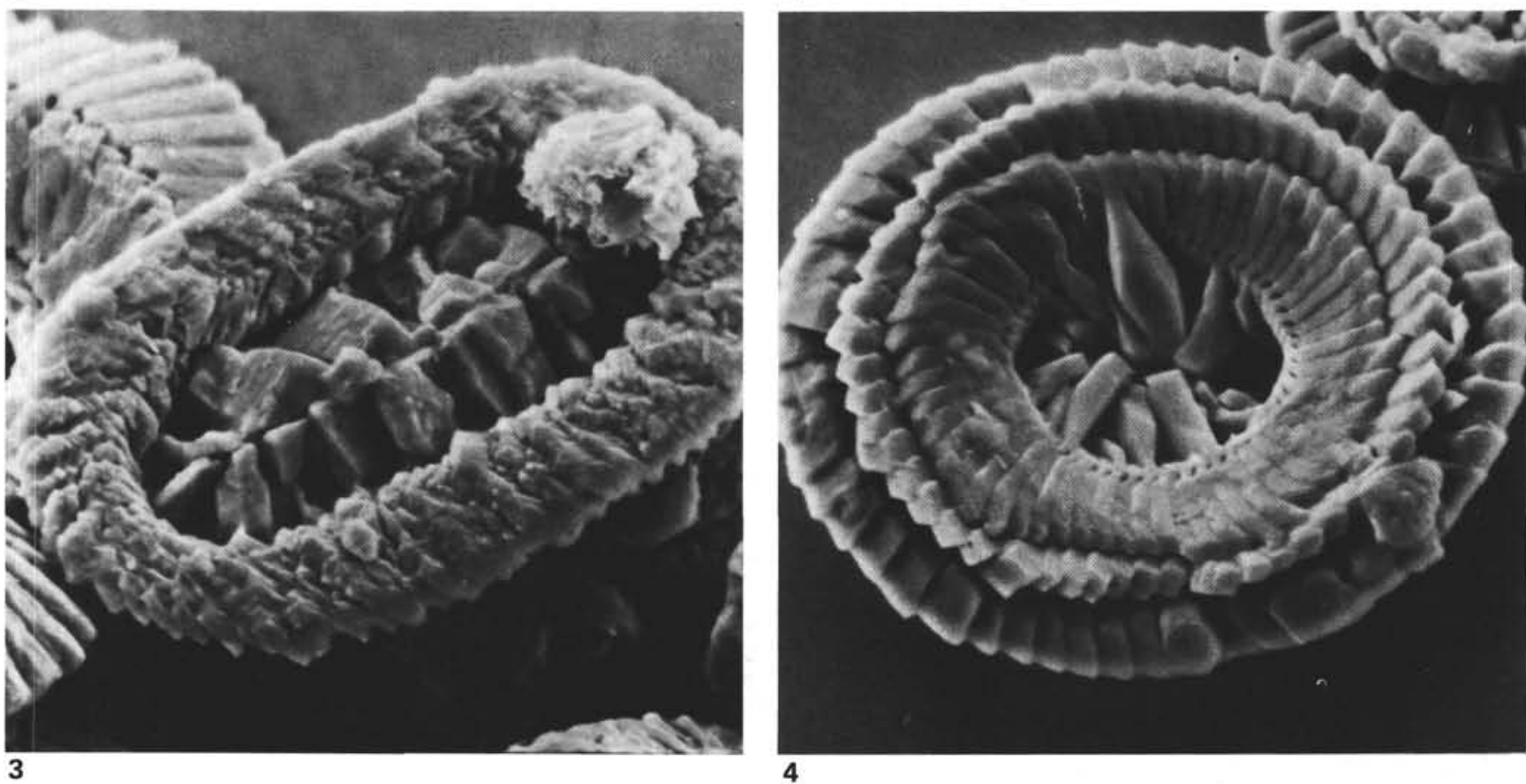

3

Plate 7. 1. Ericsonia cf. E. subpertusa Hay and Mohler, proximal view, $\times 6500,245-9-3,120-122 \mathrm{~cm} .2$. Heliolithus sp. 1 in Wise and Wind, distal view?, $\times 8500$. Sample $245-9-2,120-122 \mathrm{~cm}$. 3. Ellipsolithus sp., $\times 9000$, Sample $245-9-3,120-122 \mathrm{~cm}$. 4. Ericsonia muiri (Black) Roth, proximal view, $\times 9000$, Sample $245-8-1,55-57 \mathrm{~cm}$. 

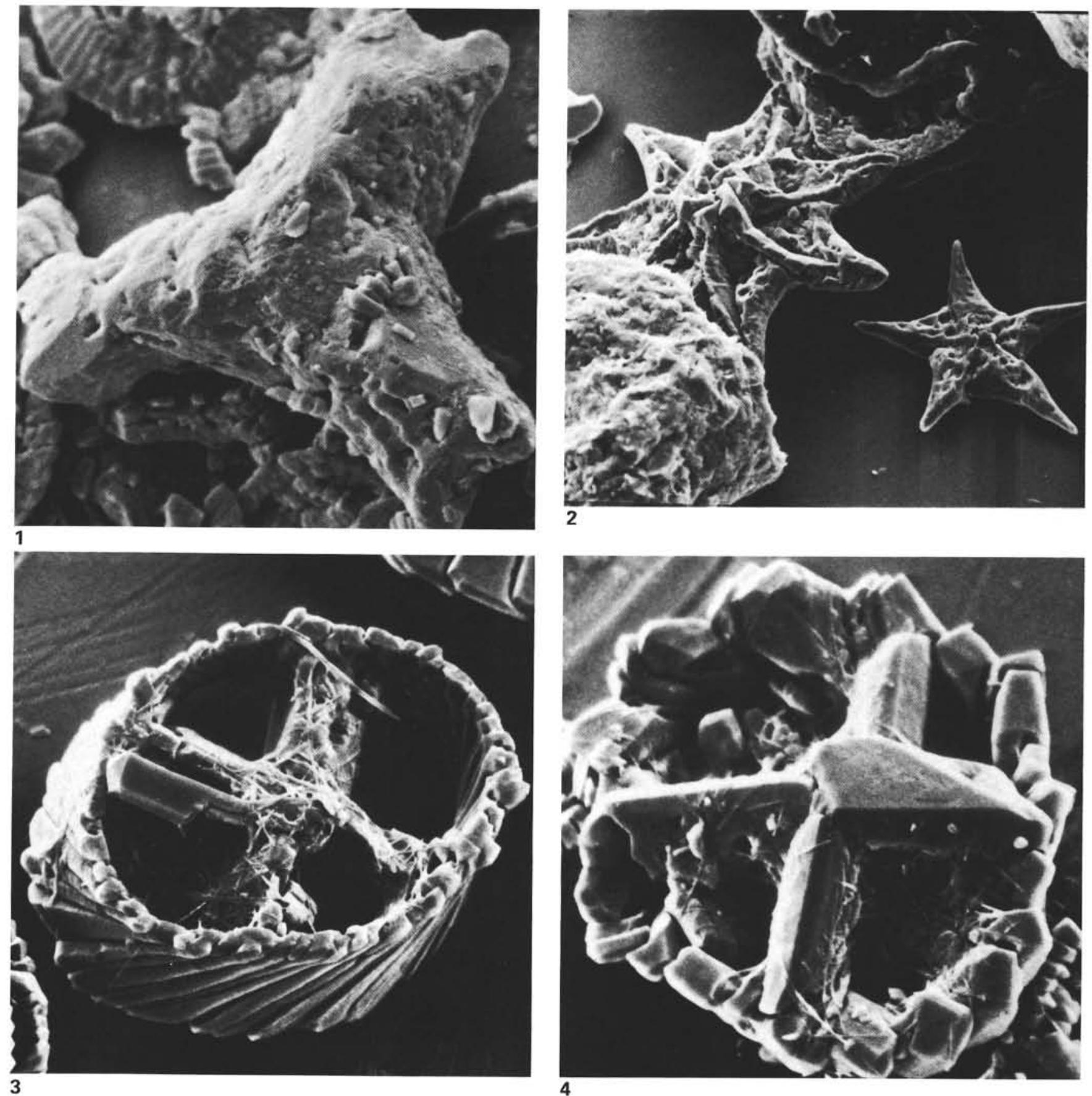

Plate 8. 1. Marthasterites contortus (Stradner) Deflandre, $\times 5000$, Sample 361-8-1, 131-133 cm. 2. Discoaster lodoensis Bramlette and Riedel (upper left) and Discoaster sublodoensis (lower right), $\times 3000$, Sample $361-5-5,125-127 \mathrm{~cm} . \quad 3$. Chiphragmalithus calathus Bramlette and Sullivan, proximal view, $\times 7500$, Sample $361-4-1,137-139 \mathrm{~cm}$. 4. Chiphragmalithus acanthodes Bramletter and Sullivan, $\times 9500$, Sample $361-4-1,137-139 \mathrm{~cm}$. 

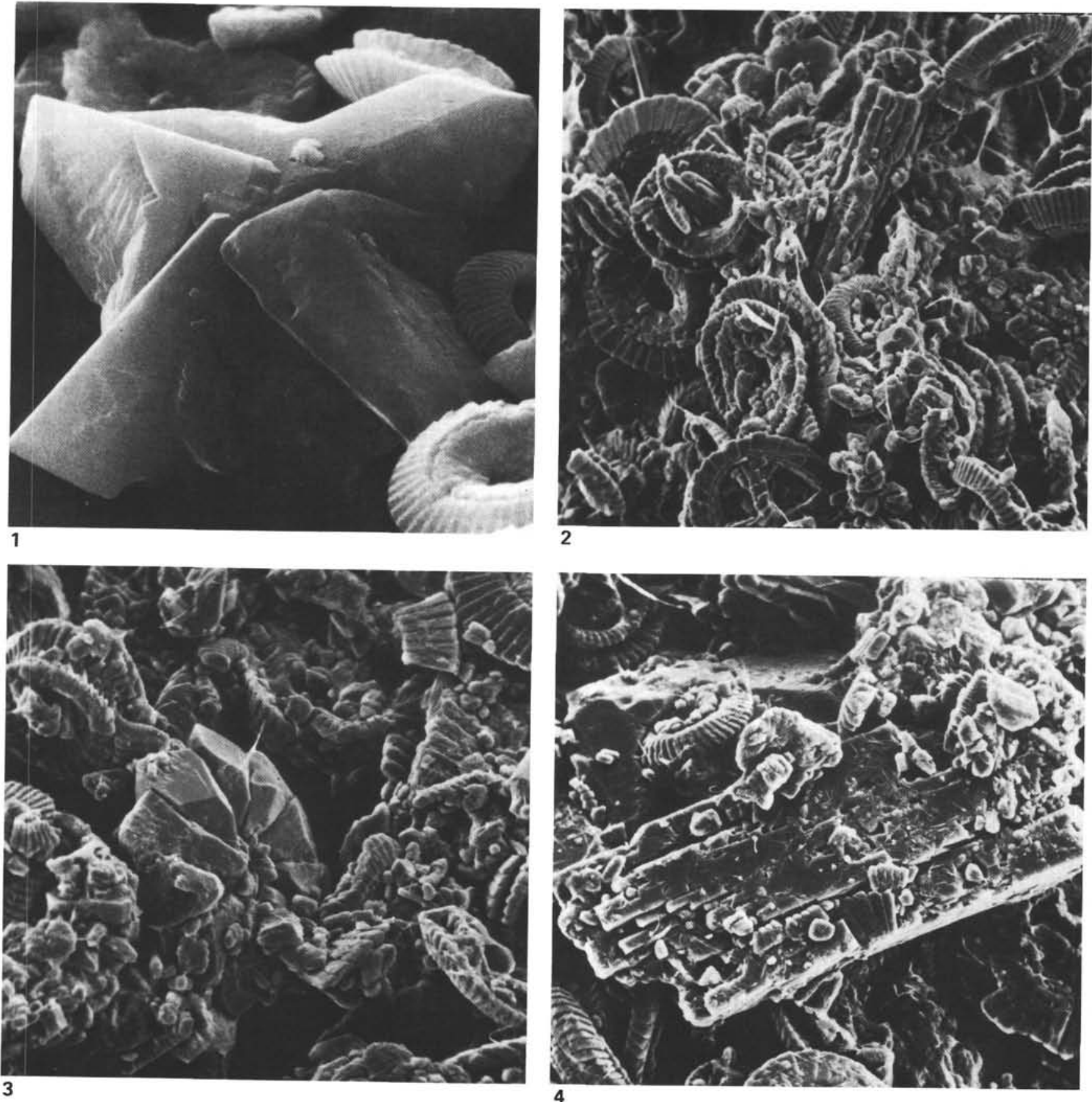

Plate 9. 1. Nannotetrina fulgens (Stradner) Stradner, $\times 5000$, Sample 245-3-5, 91-92 cm. 2-4. Fracture section showing (2) partially dissolved and fragmented coccoliths and coccolith elements; (3) blocky calcite overgrowth on Discoaster barbadiensis; (4) most coccoliths broken and partially dissolved, and strongly overgrown by large masses of what appears to be calcite attached at the upper right; Sample 245-3-5, 91-92 cm $\times 3100,4500 \times$, and $3900 \times$, respectively. 

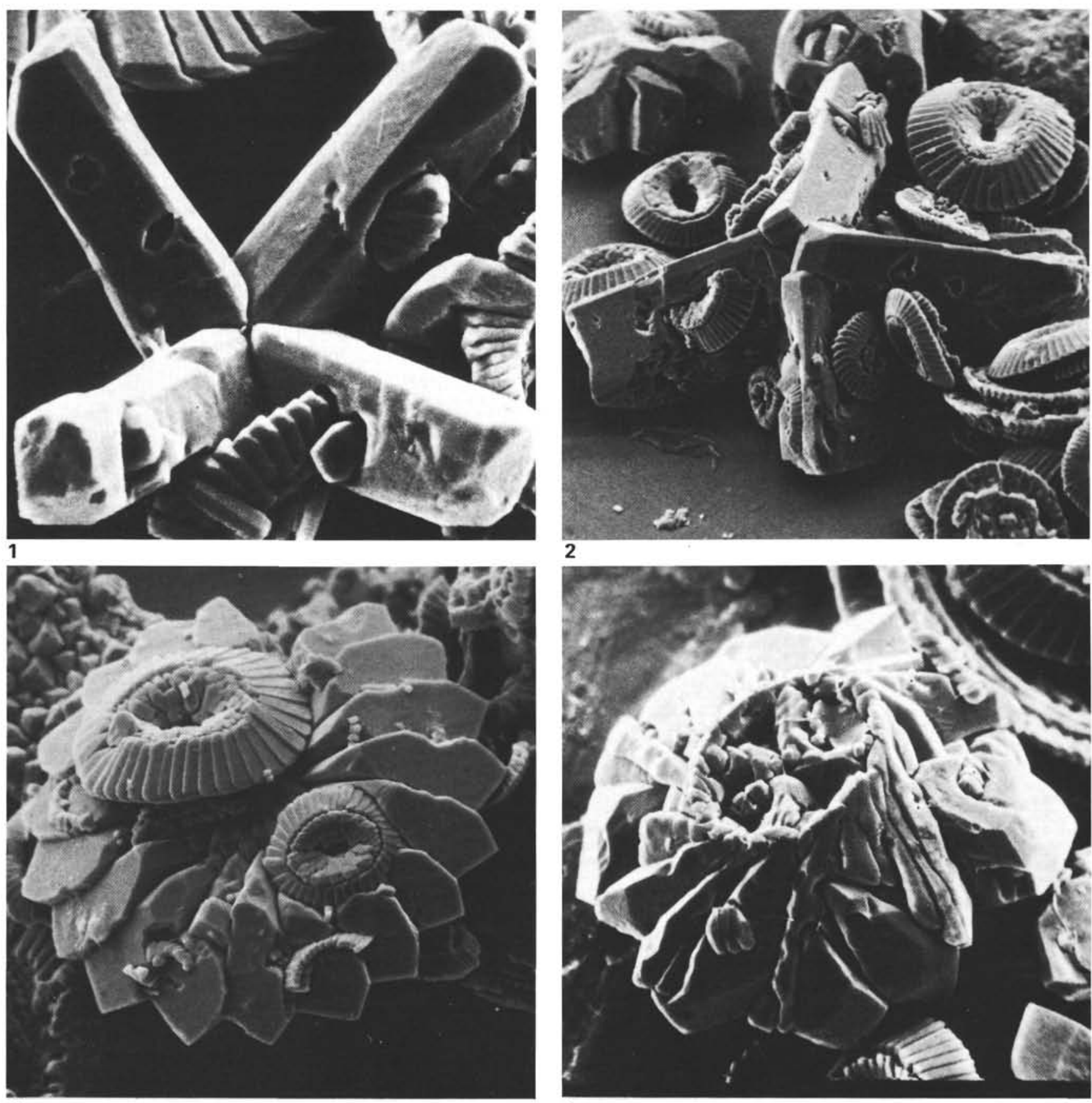

3

4

Plate 10. 1. Discoaster cruciformis Martini, $\times 9500$, Sample 361-4-7, 137-139 cm. 2. Discoaster cruciformis Martini, $\times 2600$, Sample $245-3-5$, 91-92 cm. 3. Discoaster barbadiensis Tan, $\times 5000$; the small Coccolithus $\mathrm{sp}$. (center, right) is partially enveloped by the secondary calcite overgrowth on the discoaster. Sample $245-8-1,55-57 \mathrm{~cm}$. 4. Chiphragmalithus acanthodes?, $\times 5500$, heavily overgrown with secondary calcite, perhaps intergrown with species of Discoaster; Sample $361-4-1,137-139 \mathrm{~cm}$. 